\title{
Evolution of COVID-19 mortality over time: results from the Swiss hospital surveillance system (CH-SUR)
}

\author{
Maroussia Roelens ${ }^{1 *}$, Alexis Martin ${ }^{2,3 *}$, Brian Friker ${ }^{4}$, Filipe Maximiano Sousa ${ }^{4}$, Amaury Thiabaud ${ }^{1}$, Beatriz Vidondo ${ }^{4}$, \\ Valentin Buchter ${ }^{5}$, Céline Gardiol ${ }^{5}$, Jasmin Vonlanthen ${ }^{5}$, Carlo Balmelli ${ }^{6}$, Manuel Battegay ${ }^{7}$, Christoph Berger ${ }^{8}$, Michael \\ Buettcher $^{9}$, Alexia Cusini ${ }^{10}$, Domenica Flury ${ }^{11}$, Ulrich Heininger ${ }^{12}$, Anita Niederer-Loher ${ }^{13}$, Thomas Riedel ${ }^{14}$, Peter W. \\ Schreiber ${ }^{15}$, Rami Sommerstein ${ }^{16,17}$, Nicolas Troillet ${ }^{18}$, Sarah Tschudin-Sutter ${ }^{7}$, Pauline Vetter ${ }^{19}$, Sara Bernhard- \\ Stirnemann ${ }^{20}$, Natascia Corti ${ }^{21}$, Roman Gaudenz ${ }^{22}$, Jonas Marschalli6, Yvonne Nussbaumer-Ochsner ${ }^{23}$, Laurence Senn ${ }^{24}$, \\ Danielle Vuichard-Gysin ${ }^{25}$, Petra Zimmermann ${ }^{26}{ }^{27}$, Franziska Zucol ${ }^{28}$, Anne Iten ${ }^{29 *}$, Olivia Keiser ${ }^{1 *}$, CH-SUR study group

Correspondence:

Maroussia Roelens, $\mathrm{PhD}$

Institute of Global Health

University of Geneva

Campus Biotech

Chemin des Mines 9

CH-1202 Geneva

maroussia.roelens

[at]unige.ch

\section{Summary}

BACKGROUND: When the periods of time during and after the first wave of the ongoing SARS-CoV-2/COVID-19 pandemic in Europe are compared, the associated COVID-19 mortality seems to have decreased substantially. Various factors could explain this trend, including changes in demographic characteristics of infected persons and the improvement of case management. To date, no study has been performed to investigate the evolution of COVID-19 in-hospital mortality in Switzerland, while also accounting for risk factors.
METHODS: We investigated the trends in COVID-19-related mortality (in-hospital and in-intermediate/intensivecare) over time in Switzerland, from February 2020 to June 2021, comparing in particular the first and the second wave. We used data from the COVID-19 Hospitalbased Surveillance (CH-SUR) database. We performed survival analyses adjusting for well-known risk factors of COVID-19 mortality (age, sex and comorbidities) and accounting for competing risk.

RESULTS: Our analysis included 16,984 patients recorded in $\mathrm{CH}-S U R$, with 2201 reported deaths due to COVID-19 (13.0\%). We found that overall in-hospital mortality was lower during the second wave of COVID-19 than 
in the first wave (hazard ratio [HR] 0.70, 95\% confidence interval [Cl] 0.63-0.78; $p<0.001$ ), a decrease apparently not explained by changes in demographic characteristics of patients. In contrast, mortality in intermediate and intensive care significantly increased in the second wave compared with the first wave $(\mathrm{HR} 1.25,95 \% \mathrm{Cl} 1.05-1.49$; $p=$ 0.029 ), with significant changes in the course of hospitalisation between the first and the second wave.

CONCLUSION: We found that, in Switzerland, COVID-19 mortality decreased among hospitalised persons, whereas it increased among patients admitted to intermediate or intensive care, when comparing the second wave to the first wave. We put our findings in perspective with changes over time in case management, treatment strategy, hospital burden and non-pharmaceutical interventions. Further analyses of the potential effect of virus variants and of vaccination on mortality would be crucial to have a complete overview of COVID-19 mortality trends throughout the different phases of the pandemic.

\section{Introduction}

Many countries around the world, and in particular in Europe, experienced an evolution of the COVID-19 pandemic over time with a first wave occurring in Spring 2020, followed by a substantial decrease in the number of COVID-19 cases during the intermediate period, and then by the emergence of a second wave in Autumn 2020. The chronology of the different COVID-19 waves is tightly related to governments' responses to the epidemic, which varied widely over time and country, often tightening and relaxing non-pharmaceutical interventions (hereafter NPIs, i.e., infection control measures including lockdown, travel banning and the setting up of testing and tracing programmes) depending on the number of diagnosed COVID-19 cases.

The assessment of COVID-19-associated mortality is crucial not only to evaluate the impact of the pandemic, but also to evaluate the improvement of knowledge on the disease and of patient care, as well as the effectiveness of measures adopted to control the outbreak. It has been hypothesised that COVID-19 mortality might have been lower after the first wave in Europe [1-3].

Crude calculations from numbers of cases and deaths reported by the Federal Office of Public Health (FOPH) $[4,5]$ yield case fatality ratios (CFRs, i.e., the proportion of deaths among all infected persons identified) for COVID-19 in Switzerland of approximately 5.4\% between end of February and end of April 2020 (first wave), 0.94\% between early May and end of September 2020, 1.6\% from October 2020 to mid-February 2021 (second wave) and $0.6 \%$ from mid-February to end June 2021 (third wave). This change in mortality could potentially be explained by several factors. First, the restrictions on COVID-19 testing during the first wave likely resulted in a high CFR, whereas the increase in testing capacity over time and especially since November 2020 could decrease the CFR estimate over time. However, since testing restrictions were not applied to hospitalised persons, it should not affect the inhospital mortality rate (the proportion of deaths among all persons hospitalised with COVID-19 diagnosis). Then, it could relate to changes in demographic characteristics of the population. In particular, older age and comorbidities are very well-known risk factors for mortality of SARSCoV-2 infected persons [6-9]. Moreover, earlier access to medical care and improved care in hospitals could also contribute to a lower morbidity and mortality over time. Some studies showed an improvement of survival among critical care patients with COVID-19 [10], likely due to improvements in treatment strategies and management of severe cases.

To our knowledge, no study has been performed to investigate the evolution of COVID-19 related morbidity and mortality among hospitalised patients at a national scale in Switzerland, while also accounting for risk factors. Therefore, the aim of the present study was to investigate the trends in COVID-19 related mortality over time in Switzerland, comparing in particular the first and the second wave, using data from the COVID-19 Hospital-based Surveillance (CH-SUR) database [11].

\section{Materials and methods}

\section{Data source}

CH-SUR (COVID-19 Hospital Based Surveillance) is a prospective hospital surveillance system for COVID-19 coordinated by the Swiss Federal Office of Public Health (FOPH) and the Institute of Global Health (ISG) of the University of Geneva [11, 12], designed to capture detailed information on COVID-19 hospitalised patients in Switzerland. It includes patients hospitalised for more than 24 hours and diagnosed with COVID-19 confirmed by a laboratory test (e.g., polymerase chain-reaction test, PCR), plus those confirmed by a serology or with a computed tomography (CT) scan and thorax radiography compatible with COVID-19 diagnosis since 14 November 2020. To date, 21 Swiss hospitals are participating in this surveillance (including university hospitals and cantonal hospitals), spread all over Switzerland, and accounting for most of the hospitalisations related to COVID-19 in Switzerland, ensuring that $\mathrm{CH}-\mathrm{SUR}$ data are representative of the overall COVID-19 situation in the country [9].

For each COVID-19 episode recorded in CH-SUR, information on demographics, admission, clinical information (including comorbidities, complications, admission to intermediate care unit and/or intensive care unit - hereafter IMCU/ICU - and treatments) and follow-up (death, discharge or transfer) are collected. Further information on $\mathrm{CH}-\mathrm{SUR}$ can be found elsewhere [11]. Of note, since $\mathrm{CH}-$ SUR was set up first for surveillance purposes, in a period of high burden for participating hospitals, priority was given to collection of data on admission and follow-up, to enable timely estimates of numbers of new cases and outcomes. Hence, the documentation of additional complementary information (which is relatively time-consuming) is optional, and is often provided with some delay compared with the mandatory information on admission and follow-up. At the time of data export, the clinical complementary information was complete for more than $90 \%$ of recorded episodes

For that analysis, we included all adult (age $\geq 18$ years) patients in CH-SUR diagnosed between 24 February 2020 and 20 June 2021, as recorded by 10 August 2021. Out of the 21 hospitals participating in CH-SUR, one had too incomplete data to be included in our analysis (clinical com- 
plementary information provided for less than $50 \%$ of patients), and 6 were paediatric hospitals (hence reporting no adult case), consequently the data we used was collected from only 14 hospitals.

This study was submitted and approved by the Geneva Ethics Committee (CCER) and by all hospitals' local Ethics Committees through the Swiss ethics BASEC submission system, under reference 2020-00827.

\section{Statistical analysis}

We investigated four different time periods in our analyses, corresponding to the different waves of COVID-19 observed in Switzerland, which are defined in table 1. The outcome of a COVID-19 episode was either death due to COVID-19, death due to a cause other than COVID-19, discharge (including both recovered patients who went home and those discharged - presumably not infectious any more - to a nursing home) or transfer to a hospital outside the surveillance network. Patients with no outcome documented were assumed to be still in care.

We conducted a survival analysis, for which time-to-event was calculated from the date of the first COVID-19 diagnosis (i.e., date of first sample positive for SARS-CoV-2 infection or date of first clinical diagnosis with imaging) to either the date of outcome or the censoring date. We accounted for competing risks, with death due to COVID-19 being the outcome of interest, and death due to other causes, discharge and transfer being considered as competing risks. Patients still in care were censored at the date of the data export (10 August 2021) [13].

We calculated crude cumulative incidence functions (CIFs) for death, overall and per time period, using the $\mathrm{R}$ package mstate $[13,14]$. We used univariable and multivariable Fine and Gray models [15] to determine risk factors of mortality, adjusting for sex (male, female), age (as a continuous variable with restricted cubic splines [16]), time period of COVID-19 diagnosis (first wave, intermediate phase, second wave, third wave), obesity (no, yes), smoking (no, yes), chronic respiratory disease (no, yes), cardiovascular disease (no, yes), renal disease (no, yes), oncological pathologies (no, yes), dementia (no, yes), immunosuppression (no, yes). We excluded patients with missing age, sex, or outcome date when the outcome was documented. We imputed missing values of all other covariables using multiple imputation by chained equation ( $\mathrm{R}$ package mice [17]), adding the outcome and time to event to improve the results of the imputation. We ran the model on 20 imputed datasets for each analysis, and combined the estimates with Rubin's rule [17]. For patients with multiple hospitalisations recorded in CH-SUR, we used the information on comorbidities provided at the first admission. We considered only the outcome of the last hospitalisation, and time-to-event was defined as the time from the date of first
COVID-19 diagnosis to the date of the last outcome (or the time of censoring if considered still in care).

In a sensitivity analysis, we recalculated univariable and multivariable Fine and Gray models without multiple imputation, excluding all patients with incomplete information on any of the adjusted covariables. We also calculated univariable and multivariable Cox models, hence without accounting for competing risk, with and without multiple imputation, for comparison purposes. Finally, we re-ran all the aforementioned analyses with all-cause death among COVID-19 infected patients of CH-SUR being the outcome of interest, this time not distinguishing death due to COVID-19 from other causes of death.

\section{Patients on intensive and intermediate care}

Similar analyses were conducted for the subgroup of patients who have ever been admitted to IMCU/ICU during their COVID-19 episode(s), with time-to-event being defined as the time from first admission in IMCU/ICU to either the date of outcome or the censoring date. Risk factors of mortality among the IMCU/ICU subgroup were explored using Fine and Gray models as detailed above. For sensitivity purposes, we repeated these analyses but including only patients ever admitted to ICU.

\section{Results}

\section{Characteristics of COVID-19 patients}

As of 10 August 2021, 16,984 patients recorded in $\mathrm{CH}$ SUR were included in our analysis with 2458 reported deaths $(14.5 \%), 2201$ of which were reported to be due to COVID-19 (13.0\%). Characteristics of included patients overall and for the first and second waves of COVID-19, are shown in tables 2 and 3 . The complete table of characteristics of all the included patients, overall and stratified by time period of COVID-19 diagnosis, can be found in appendix 1 .

Of 2201 deaths due to COVID-19 recorded in CH-SUR by the date of data export, 438 patients were diagnosed during the first wave, and 1485 during the second wave. Crude in-hospital COVID-19 mortality was of $15.6 \%$ for patients diagnosed during the first wave and $13.9 \%$ for those diagnosed during the second wave. Hospitalised COVID-19 patients were slightly older in the second wave (median 73 years, interquartile range [IQR] 61-82) than in the first wave (median 69 years, IQR 55-80). The proportion of male patients was lower in the second wave $(57.5 \%)$ than in the first wave $(60.1 \%)$. Low severity scores at admission (CURB-65 score) tended to be more frequent in the second wave $(20.9 \%$ with score $0,37.7 \%$ with score $1,29.0 \%$ with score 2$)$ compared with the first wave (31.0\% with score 0 , $33.5 \%$ with score $1,23.9 \%$ with score 2 .

Table 1:

Definition of time periods for COVID-19 waves in Switzerland.

\begin{tabular}{|l|l|l|}
\hline Time period & Start date & End date \\
\hline First wave & $2020-02-24$ & $2020-04-30$ \\
\hline Intermediate phase & $2020-05-01$ & $2020-09-30$ \\
\hline Second wave & $2020-10-01$ & $2021-02-14$ \\
\hline Third wave & $2021-02-15$ & $2021-06-20$ \\
\hline
\end{tabular}

Date format: yyyy-mm-dd 
Because the clinical complementary information is often entered in the database with some delay, data on comorbidities were less complete for the second wave than for the first wave $(3.4 \%$ and $0 \%$, respectively, of patients with missing information or presence of any comorbidity). Based on the available data, hospitalised patients diag-

Table 2:

Distribution of outcomes for the included COVID-19 patients. P-value corresponds to comparison between the first wave and the second wave, from a chi-square test.

\begin{tabular}{|l|l|l|l|l|}
\hline & All, $\mathbf{n = 1 6 , 9 8 4}$ & First wave, $\mathbf{n = 2 8 0 8}$ & Second wave, $\mathbf{n}=\mathbf{1 0 , 6 5 3}$ \\
\hline Censored & $638(3.8 \%)$ & $2(0.1 \%)$ & $440(4.1 \%)$ & P-value, ${ }^{\text {st }}$ wave $/ \mathbf{2}^{\text {nd }}$ wave \\
\hline Deceased - COVID-19 & $2201(13 \%)$ & $438(15.6 \%)$ & $1485(13.9 \%)$ \\
\hline Deceased - other & $257(1.5 \%)$ & $12(0.4 \%)$ & $211(2 \%)$ \\
\hline Discharged & $13,386(78.8 \%)$ & $2240(79.8 \%)$ & $8216(77.1 \%)$ \\
\hline Transferred & $502(3 \%)$ & $116(4.1 \%)$ & $301(2.8 \%)$ \\
\hline
\end{tabular}

Table 3:

Characteristics of COVID-19 patients. For continuous variables, the values given are median (interquartile range). For categorical variables, percentages provided are calculated with respect to total number of patients. P-values correspond to comparison between the first wave and the second wave, from Kruskal-Wallis rank-sum test for continuous variables and chi-square test for categorical variables.

\begin{tabular}{|c|c|c|c|c|c|}
\hline & & All, $\mathrm{n}=16984$ & First wave, $\mathbf{n}=\mathbf{2 8 0 8}$ & Second wave, $n=10,653$ & P-value, 1 st wave / $2^{\text {nd }}$ wave \\
\hline \multicolumn{2}{|c|}{ Time from diagnosis to outcome or censoring (d) } & $13(7-21)$ & $11(621)$ & $13(722)$ & $P<0.001$ \\
\hline \multicolumn{2}{|c|}{ Time from symptoms onset to diagnosis (d) } & $2(06)$ & $4(17)$ & $2(05)$ & $P<0.001$ \\
\hline \multicolumn{2}{|c|}{ Time from hospital admission to outcome (d) } & $9(519)$ & $10(520)$ & $10(519)$ & $P=0.38$ \\
\hline \multicolumn{2}{|c|}{ Time from diagnosis to hospital admission (d) } & $0(04)$ & $0(02)$ & $0(04)$ & $P<0.001$ \\
\hline \multicolumn{2}{|l|}{ Age (years) } & $71(5881)$ & $69(5580)$ & $73(61-82)$ & $P<0.001$ \\
\hline \multirow[t]{2}{*}{ Sex } & Female & $7187(42.3 \%)$ & $1119(39.9 \%)$ & $4527(42.5 \%)$ & \multirow[t]{2}{*}{$P=0.012$} \\
\hline & Male & $9797(57.7 \%)$ & $1689(60.1 \%)$ & $6126(57.5 \%)$ & \\
\hline \multirow[t]{3}{*}{ Obesity } & No & $9195(54.1 \%)$ & $1377(49 \%)$ & $5997(56.3 \%)$ & \multirow[t]{3}{*}{$P<0.001$} \\
\hline & Yes & $4375(25.8 \%)$ & $619(22 \%)$ & $2707(25.4 \%)$ & \\
\hline & Unknown & $3414(20.1 \%)$ & $812(28.9 \%)$ & $1949(18.3 \%)$ & \\
\hline \multirow[t]{3}{*}{ Smoking } & No & $9192(54.1 \%)$ & $1671(59.5 \%)$ & $5540(52 \%)$ & \multirow[t]{3}{*}{$P<0.001$} \\
\hline & Yes & $1765(10.4 \%)$ & $235(8.4 \%)$ & $1111(10.4 \%)$ & \\
\hline & Unknown & $6027(35.5 \%)$ & $902(32.1 \%)$ & $4002(37.6 \%)$ & \\
\hline \multirow[t]{3}{*}{ Renal disease } & No & $13,326(78.5 \%)$ & $2338(83.3 \%)$ & $7962(74.7 \%)$ & \multirow[t]{3}{*}{$P<0.001$} \\
\hline & Yes & $3207(18.9 \%)$ & $466(16.6 \%)$ & $2304(21.6 \%)$ & \\
\hline & Unknown & $451(2.7 \%)$ & $4(0.1 \%)$ & $387(3.6 \%)$ & \\
\hline \multirow[t]{3}{*}{ Oncological pathology } & No & $14,489(85.3 \%)$ & $2513(89.5 \%)$ & $8841(83 \%)$ & \multirow[t]{3}{*}{$P<0.001$} \\
\hline & Yes & $2030(12 \%)$ & $290(10.3 \%)$ & $1417(13.3 \%)$ & \\
\hline & Unknown & $465(2.7 \%)$ & $5(0.2 \%)$ & $395(3.7 \%)$ & \\
\hline \multirow[t]{3}{*}{ Chronic respiratory disease } & No & $13,224(77.9 \%)$ & $2189(78 \%)$ & $8153(76.5 \%)$ & \multirow[t]{3}{*}{$P<0.001$} \\
\hline & Yes & $3310(19.5 \%)$ & $613(21.8 \%)$ & $2116(19.9 \%)$ & \\
\hline & Unknown & $450(2.6 \%)$ & $6(0.2 \%)$ & $384(3.6 \%)$ & \\
\hline \multirow[t]{3}{*}{ Cardiovascular disease } & No & $10,811(63.7 \%)$ & $1925(68.6 \%)$ & $6271(58.9 \%)$ & \multirow[t]{3}{*}{$P<0.001$} \\
\hline & Yes & $5730(33.7 \%)$ & $883(31.4 \%)$ & $4006(37.6 \%)$ & \\
\hline & Unknown & $443(2.6 \%)$ & $0(0 \%)$ & $376(3.5 \%)$ & \\
\hline \multirow[t]{3}{*}{ Dementia } & No & $15,045(88.6 \%)$ & $2609(92.9 \%)$ & $9132(85.7 \%)$ & \multirow[t]{3}{*}{$P<0.001$} \\
\hline & Yes & $1461(8.6 \%)$ & $190(6.8 \%)$ & $1117(10.5 \%)$ & \\
\hline & Unknown & $478(2.8 \%)$ & $9(0.3 \%)$ & $404(3.8 \%)$ & \\
\hline \multirow[t]{3}{*}{ Immunosuppression } & No & $15,118(89 \%)$ & $2556(91 \%)$ & $9345(87.7 \%)$ & $P<0.001$ \\
\hline & Yes & $1371(8.1 \%)$ & $217(7.7 \%)$ & $912(8.6 \%)$ & \\
\hline & Unknown & $495(2.9 \%)$ & $35(1.2 \%)$ & $396(3.7 \%)$ & \\
\hline Any comorbidity & No & $2832(16.7 \%)$ & $577(20.5 \%)$ & $1385(13 \%)$ & $P<0.001$ \\
\hline & Yes & $13,746(80.9 \%)$ & $2231(79.5 \%)$ & $8910(83.6 \%)$ & \\
\hline & Unknown & $406(2.4 \%)$ & $0(0 \%)$ & $358(3.4 \%)$ & \\
\hline CURB-65 score & 0 & $4441(26.1 \%)$ & $870(31 \%)$ & $2230(20.9 \%)$ & $P<0.001$ \\
\hline & 1 & $6214(36.6 \%)$ & $940(33.5 \%)$ & $4011(37.7 \%)$ & \\
\hline & 2 & $4405(25.9 \%)$ & $672(23.9 \%)$ & $3089(29 \%)$ & \\
\hline & 3 & $1568(9.2 \%)$ & $268(9.5 \%)$ & $1078(10.1 \%)$ & \\
\hline & 4 & $320(1.9 \%)$ & $53(1.9 \%)$ & $222(2.1 \%)$ & \\
\hline & 5 & $33(0.2 \%)$ & $5(0.2 \%)$ & $22(0.2 \%)$ & \\
\hline & Unknown & $3(0 \%)$ & $0(0 \%)$ & $1(0 \%)$ & \\
\hline Ever admitted to ICU & No & $13,752(81 \%)$ & $2272(80.9 \%)$ & $8715(81.8 \%)$ & $P<0.001$ \\
\hline & Yes & $2723(16 \%)$ & $534(19 \%)$ & $1576(14.8 \%)$ & \\
\hline & Unknown & $509(3 \%)$ & $2(0.1 \%)$ & $362(3.4 \%)$ & \\
\hline Ever admitted to IMCU/ICU & No & $12,742(75 \%)$ & $1988(70.8 \%)$ & $8179(76.8 \%)$ & $P<0.001$ \\
\hline & Yes & $3750(22.1 \%)$ & $819(29.2 \%)$ & $2112(19.8 \%)$ & \\
\hline & Unknown & $492(2.9 \%)$ & $1(0 \%)$ & $362(3.4 \%)$ & \\
\hline
\end{tabular}


nosed during the second wave appeared to be more comorbid than those diagnosed during the first wave $(86.5 \%$ and $79.5 \%$, respectively, of patients who had information on presence or absence of comorbidities available).

The median time from first COVID-19 diagnosis to outcome (or censoring), was 11 days (IQR 6-21) for the first wave and 13 days (IQR 7-22) for the second wave. For patients who died due to COVID-19, median time-to-event was 9 days (IQR 6-15) in the first wave compared with 12 days (IQR 6-20) in the second wave. Further statistics on time-to-event stratified per outcome and per time period are provided in appendix 2 . The duration of hospital stay was similar between the first (median 10 days, IQR 5-22) and the second waves (median 10 days, IQR 5-19). Time from diagnosis to first hospital admission was often equal to zero in both waves, meaning that most patients are tested at hospital entry, however it tended to be shorter in the first wave (3rd quartile 2 days) than in the second wave (3rd quartile 4 days).

\section{Differences in overall in-hospital COVID-19 mortality by time period}

Figure 1 shows cumulative incidence functions of death due to COVID-19 for each time period. Similar figures for the other outcomes (discharge, transfer, death due to other causes) can be found in appendix 3. For the first wave, about $75 \%$ of deaths occurred within 15 days after diagnosis, and the probability of death increased from $5.1 \%$ 1 week after diagnosis to $10.7 \%$ after 2 weeks, $14.0 \%$ after 4 weeks and $15.1 \%$ after 6 weeks. In contrast, for the second wave, about $66 \%$ of deaths occurred within 15 days after diagnosis and the probability of death increased from $3.6 \%$ after 1 week to $8.3 \%$ after 2 weeks, $12.2 \%$ after 4 weeks and $13.3 \%$ after 6 weeks. This indicates that the probability of death was lower in the second wave than in the first wave and that death tended to occur later after diagnosis in the second wave compared with the first wave.

Figure 1: Cumulative incidences of death due to COVID-19 in $\mathrm{CH}$ SUR, for the different waves of COVID-19.

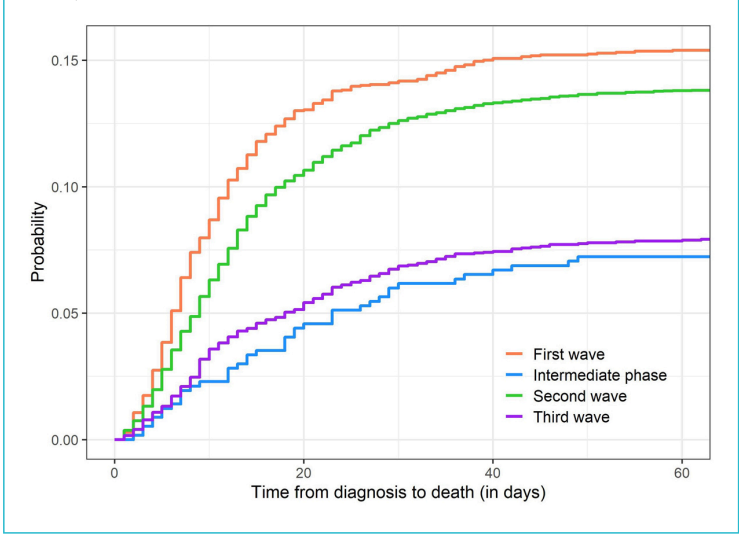

Table 4 shows the hazard ratios (HRs) for in-hospital COVID-19 mortality for the different time periods, with $95 \%$ confidence intervals $(95 \% \mathrm{CIs})$, from the Fine and Gray models. HRs and 95\% CIs for all the covariables included in the models can be found in appendix 4. The risk of death due to COVID-19 was lower for hospitalised patients diagnosed during the second wave compared with those diagnosed during the first wave (HR $0.70,95 \%$ CI 0.63-0.78).

For comparison purposes, HRs for in-hospital COVID-19 mortality from Cox models (hence not accounting for competing risk), with and without multiple imputation, can be found in appendix 5. Results from sensitivity analyses on in-hospital all-cause mortality in CH-SUR (Fine-Gray models and Cox models, with and without imputation) are shown in appendix 6 and appendix 7, respectively.

\section{Analysis of patients admitted to IMCU/ICU}

As of 10 August 2021, out of the 16,984 patients included in the main analysis, 3750 patients $(22.1 \%)$ were admitted at least once to IMCU/ICU: 819 in the first wave and 2,112 in the second wave. Overall, for 3739 of them the time to event variable was available ( 819 for the first wave, 2106 for the second wave), with time to event being defined as time from first IMCU/ICU admission to outcome (or censoring). Characteristics of all those IMCU/ICU patients, overall and stratified by time period of COVID-19 diagnosis, can be found in appendix 8 . The proportion of patients ever admitted to IMCU/ICU was lower in the second wave than in the first wave (table 3). The time elapsed from COVID-19 diagnosis to first admission into IMCU/ICU was longer in the second wave (median 4 days, IQR 0-8) than in the first wave (median 2 days, IQR $0-5$ ). The time from first IMCU/ICU admission to outcome (or censoring) was similar in the second wave (median 16 days, IQR 9-30) and in the first wave (median 16 days, IQR 8-33.5). Moreover, the proportion of patients who ever went to IM$\mathrm{CU} / \mathrm{ICU}$ and experienced invasive ventilation was higher in the first wave $(53.5 \%)$ compared with the second wave (45.2\%).

Similarly to all hospitalised patients, IMCU/ICU patients of the second wave were more comorbid than those of the first wave $(87.9 \%$ versus $81.9 \%)$. Crude in-hospital COVID-19 mortality rates among patients who were admitted to IMCU/ICU are $19.3 \%$ and $27.4 \%$ for patients hospitalised during the first wave, and second wave, respectively.

Cumulative incidence functions for death due to COVID-19 during the different waves, limited to patients ever admitted to IMCU/ICU, are shown in figure 2. Similar CIFs for the other outcomes (death due to other causes, discharge and transfer) can be found in appendix 9. During the first wave, about $82 \%$ of deaths occurred within 4

Table 4:

Estimates of the effect of time period of diagnosis on cause-specific mortality (associated to COVID-19) among hospitalised patients, from Fine and Gray models.

\begin{tabular}{|l|l|l|l|}
\hline Time period & Multivariable, imputed & Multivariable, complete case & Univariable, complete case \\
\hline & $\mathrm{p}<0.001$ & $\mathrm{p}<0.001$ & $\mathrm{p}<0.001$ \\
\hline First wave & 1.0 (ref.) & 1.0 (ref.) & 1.0 (ref.) \\
\hline Intermediate phase & $0.495(0.359-0.682)$ & $0.666(0.449-0.989)$ & $0.439(0.319-0.604)$ \\
\hline Second wave & $0.7(0.629-0.779)$ & $0.729(0.625-0.849)$ & $0.876(0.788-0.975)$ \\
\hline Third wave & $0.645(0.55-0.756)$ & $0.667(0.535-0.832)$ & $0.488(0.417-0.572)$ \\
\hline
\end{tabular}


weeks after first admission to IMCU/ICU; the probability of death among IMCU/ICU patients increased from 5.9\% after 1 week to $11.4 \%$ after 2 weeks, $15.9 \%$ after 4 weeks and $18.2 \%$ after 6 weeks. During the second wave, about $88 \%$ of deaths occurred within 4 weeks after first admission to IMCU/ICU; the probability of death increased from $8.2 \%$ after 1 week to $14.8 \%$ after 2 weeks, $23.6 \%$ after 4 weeks and $26.0 \%$ after 6 weeks. This indicates that the probability of death among IMCU/ICU patients was higher in the second wave than in the first wave, and that death tended to occur earlier after IMCU/ICU admission in the second wave compared with the first wave.

HRs associated with time period and use of invasive ventilation from Fine and Gray models are shown in table 5. HRs and 95\% CIs for all the covariables included in the models can be found in appendix 10. The risk of death was higher for patients who ever were admitted to IMCU/ICU during the second wave compared to the first wave (HR $1.25,95 \%$ CI $1.05-1.49$ ).

For comparison purposes, HRs for in-IMCU/ICU COVID-19 mortality from Cox models (hence not accounting for competing risk), with and without multiple imputation, can be found in appendix 11. Results from sensitivity analyses on in-IMCU/ICU all-cause mortality in CH-SUR (Fine-Gray models and Cox models, with and without imputation) are shown in appendix 12 and appendix 13 , respectively.

Finally, results from ICU-specific analysis can be found in appendix 14 (characteristics of patients), appendix 15 (CIFs) and appendix 16 (HRs for in-ICU COVID-19 mortality from Fine-Gray models). The proportion of patients who ever were admitted to ICU was lower in the second wave than in the first wave (table 2). During the second wave, compared with the first wave, ICU patients had a longer time from diagnosis to first ICU admission (medi-

Figure 2: Cumulative incidence functions of death due to COVID-19 for patients admitted to IMCU/ICU, for the different time periods.

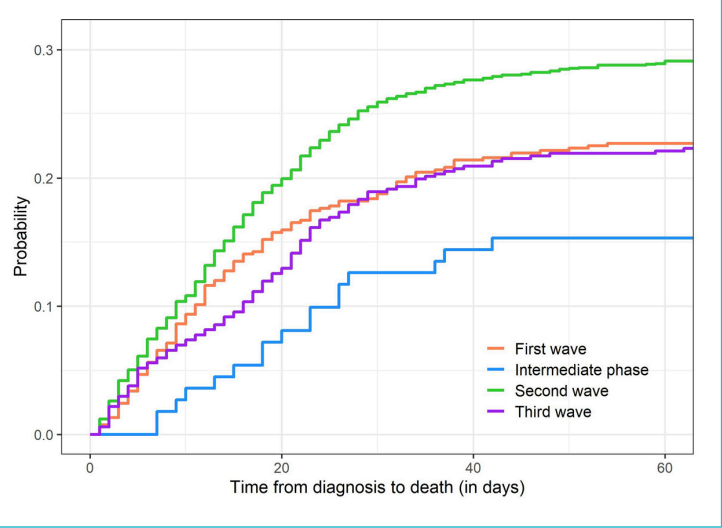

an 4 days IQR $0-8$, versus median 3 days IQR $0-6$ ), shorter time from first ICU admission to outcome (median 18 days, IQR 10-33, versus median 23 days IQR 12-41 days), a significantly lower use of invasive ventilation $(60.6 \%$ versus $82.2 \%$ ), and a possibly increased risk of death though the difference between the two waves does not appear to be very significant (HR 1.17, 95\% CI 0.96-1.43, p $=0.13$ ).

\section{Discussion}

Based on CH-SUR data, we investigated the changes of in-hospital COVID-19 mortality over time in Switzerland, accounting for well-known risk factors for mortality such as age, sex or comorbidities. In-hospital mortality due to COVID-19 was lower and the time from diagnosis to death was longer during the second wave of COVID-19 compared with the first wave.

In contrast, in-IMCU/ICU mortality due to COVID-19 significantly increased in the second wave compared with the first wave. Time from diagnosis to first IMCU/ICU admission was longer in the second wave than in the first wave. Time from first IMCU/ICU admission to outcome appeared to be similar between the first and the second waves, whereas time from first ICU admission to outcome appeared to be shorter in the second wave. The use of invasive ventilation was significantly less frequent in the second wave, whereas the use of non-invasive ventilation increased from the first to the second wave.

The lower in-hospital COVID-19 mortality observed in $\mathrm{CH}-\mathrm{SUR}$ for the second wave seems not to be explained by changes in the demographic characteristics of patients, since patients during the second wave tended to be slightly older, more comorbid, and they were more often male (all three being known to increase the risk of COVID-19-related death [6-9]). However, the changes in case management over time, induced by a growing knowledge on COVID-19, probably played a role in reducing in-hospital mortality. The use of corticosteroids (e.g., dexamethasone), which is recommended systematically since summer 2020 by World Health Organization for patients with severe or critical COVID-19 [18], and which was widely used during the second wave, has been shown to reduce mortality among patients receiving oxygen or invasive ventilation [19].

Moreover, a significantly lower referral rate of patients with a poor prognosis in the second wave could also have contributed to the reduction of observed in-hospital mortality over time while increasing the out-of-hospital mortality. Such a phenomenon could concern typically over-80-yearold persons who would have been hospitalised during the first wave but who were not because of their serious prog-

Table 5:

Estimates of the effect of time period and invasive ventilation on cause-specific (i.e., due to COVID-19) mortality among patients who ever went to IMCU/ICU, from Fine and Gray models.

\begin{tabular}{|l|l|l|l|}
\hline Time period & Multivariable, imputed & Multivariable, complete case & Univariable, complete case \\
\hline & $\mathrm{p}=0.029$ & $\mathrm{p}=0.2$ & $\mathrm{p}<0.001$ \\
\hline First wave & 1.0 (ref.) & 1.0 (ref.) & 1.0 (ref.) \\
\hline Intermediate phase & $0.824(0.532-1.28)$ & $1.12(0.641-1.97)$ & $0.788(0.509-1.22)$ \\
\hline Second wave & $1.25(1.05-1.49)$ & $1.33(1.02-1.74)$ & $1.49(1.25-1.78)$ \\
\hline Last period & $1.17(0.931-1.48)$ & $1.27(0.907-1.78)$ & $1.07(0.852-1.34)$ \\
\hline
\end{tabular}


nosis and the heaviness of acute care (either according to their will or due to triage [20]).

Compared with neighbouring countries in Western Europe, Switzerland had a lower in-hospital mortality (first wave $15.6 \%$, second wave $14.0 \%$ ) than, for example, France (first wave $16.2 \%$, second wave $17.7 \%$ ) [21] or Germany (first wave $19.1 \%$, second wave $19.8 \%$ ) [22], during both waves. This is a probable consequence of the good general health condition in Switzerland (reflected by one of the highest life expectancy worldwide [23]), a country with a well-developed health system, where comorbidities known as risk factors for COVID-19 mortality (e.g., cardiovascular diseases) are carefully controlled.

However, Switzerland was less successful at containing the pandemic during the second wave than other European countries. Its overall mortality (e.g. number of deaths per million, see [7]) and excess mortality [24] both increased during the second wave, despite being among the lowest in Europe during the first wave. This discrepancy between the time trends of in-hospital mortality and overall mortality related to COVID-19 further supports the hypothesis of increased out-of-hospital mortality during the second wave.

The characteristics of IMCU/ICU and ICU patients in CHSUR during the first and second wave revealed significant changes in the case management and in the course of hospitalisation of COVID-19 patients. Those observations are in line with the updated guidelines in Swiss hospitals regarding acute care of hospitalised COVID-19 patients [25-28]. After the first COVID-19 wave, admission in ICU was avoided or postponed as much as possible, limiting it to the most severe cases, with a wider use of intermediate care facilities in hospitals having such a unit. Moreover, invasive ventilation, which was used for most ICU patients during the first wave, was partly replaced by non-invasive ventilation or high-flow nasal cannula [29] when possible, to avoid the risks associated with mechanical ventilation, including bacterial or fungal co-infections [30].

The higher in-IMCU/ICU COVID-19 mortality observed in $\mathrm{CH}-\mathrm{SUR}$ for the second wave could be a consequence of the high burden of COVID-19 cases on Swiss hospitals in the early weeks of the second wave, up to the saturation of ICU capacity in several cantons (particularly in the western part of Switzerland) in November 2020. After that date, when the epidemic was increasing exponentially, NPIs were re-introduced, whereas the stringency index was relatively low in the preceding weeks compared with neighbouring western European countries [31, 32]. Alternatively, given the longer time elapsed between diagnosis and first IMCU/ICU admission in the second wave, patients admitted to ICU might have been in a more severe condition during the second wave, subsequently leading to worse outcomes, possibly due to delayed optimal care.

To our knowledge, this is one of the first studies investigating the time trends of COVID-19 related in-hospital mortality in Switzerland. Use of CH-SUR data allowed us to perform analyses including clinical information on comorbidities and ensured a high coverage of COVID-19 hospitalisations in Switzerland, with about $70 \%$ of all hospitalisations reported mandatorily to the FOPH by 21 June 2021 included in CH-SUR. By imputing missing values of covariables, accounting for competing risks and including age as a continuous variable (instead of categorising it ar- bitrarily), we improved the accuracy of our approach. In contrast, as our study used observational patient data, it may be subject to some biases, such as selection or information bias [33]. Another limitation of our study is that, for some models and some variables, the proportional hazard assumption inherent to Cox and Fine-Gray models was violated, hence mitigating the statistical power of our analysis.

Other studies in Europe have investigated the risk of death among patients infected by some SARS-CoV-2 variants of concern [34], such as the alpha variant, which appears to increase the risk of critical care admission and mortality compared to the common SARS-CoV-2 strain $[35,36]$, or the delta variant which was shown to double the risk of hospital admission compared to the alpha variant [37]. The emergence of several suspected more virulent variants since autumn 2020 likely influences the time trends of COVID-19-related mortality. Information on the variant type has been recorded in the CH-SUR database since January 2021 for a fraction of documented episodes. However, to date data remain very sparse, which limits analyses on the effect of variants on COVID-19 in-hospital mortality.

Vaccination should also affect significantly trends in COVID-19 mortality, by reducing the risk of developing a severe form of the disease, and therefore reducing the risk of hospitalisation and death. In Switzerland, the vaccination campaign started in early January 2021, first limited to very specific subgroups of the population. Consequently, we do not expect it to have played a role in the differences in mortality between the first and the second wave. Nevertheless, vaccination will be a key element of analyses on COVID-19 related morbidity and mortality for the subsequent waves.

In conclusion, we found that in Switzerland COVID-19 in-hospital mortality was lower during the second wave than in the first wave. In contrast, in the second wave, COVID-19-related mortality significantly increased among patients admitted to intermediate or intensive care, compared with the first wave. We put our findings in perspective with the changes operated between the two time periods in terms of case management, treatment strategy, hospital burden and NPIs. Further analyses in the near future, taking into account the potential effect of variants and vaccination on mortality, would be crucial to have a complete overview of COVID-19 mortality trends throughout the different phases of the pandemic.

\section{Accessing the data}

The anonymised data can be accessed through a multistage process described elsewhere [11]. Applicants must fill a concept-sheet and send it to the team in charge of the study. An Executive Committee of experts and representatives of hospital participants will review the concept. Depending on the goal of the analysis, additional ethics clearance might be needed. Data will be restricted to the request and shared through a secure platform.

\section{Acknowledgements}

The list of members of CH-SUR is available on the CH-SUR website: https://www.unige.ch/medecine/hospital-covid/ 
The authors would like to thank all the participating centres' teams, study nurses, and physicians for their hard work and commitment to the study. The Clinical Research Centre (Geneva University Hospitals and Faculty of Medicine) hosted the database.

\section{Statement on funding sources}

This work was supported by the Swiss Federal Office of Public Health under reference 333.0-20/1 (UniGe) and 334.0-80/1 (UniBe). O.K. acknowledges additional support from the Swiss National Science Foundation (SNF) via grant \#163878. PWS is supported by the academic career program "Filling the Gap" of the Medical Faculty of the University of Zurich.

\section{Conflict of intetest statement}

All authors have completed and submitted the International Committee of Medical Journal Editors form for disclosure of potential conflicts of interest. PWS received travel grants from Pfizer and Gilead, honoraria for advisory board activity and talks from Pfizer outside of the submitted work. All other authors declare no conflict of interest.

\section{References}

1. Cookson C, Burn-Murdoch J. Why the second wave of COVID-19 appears to be less lethal. Financial Times. 2020; Available at: https://www.ft.com/content/b3801b63-fbdb-433b-9a46-2174 05b1109f.

2. Griffin S. Covid-19: second wave death rate is doubling fortnightly but is lower and slower than in March. BMJ. 2020 Oct;371:m4092. http://dx.doi.org/10.1136/bmj.m4092. PubMed. 1756-1833

3. James N, Menzies M, Radchenko P. COVID-19 second wave mortality in Europe and the United States. Chaos. 2021 Mar;31(3):031105. http://dx.doi.org/10.1063/5.0041569. PubMed. 1089-7682

4. COVID-19 Switzerland | Coronavirus | Dashboard. Available at: https://www.covid19.admin.ch/en/overview. Accessed 2021 April 30.

5. FOPH Federal Office of Public Health. Coronavirus: Situation in Switzerland. Available at: https:/www.bag.admin.ch/bag/en/home/ krankheiten/ausbrueche-epidemien-pandemien/aktuelle-ausbrueche-epidemien/novel-cov/situation-schweiz-und-international.html. Accessed 2021 May 7.

6. Williamson EJ, Walker AJ, Bhaskaran K, Bacon S, Bates C, Morton CE, et al. Factors associated with COVID-19-related death using OpenSAFELY. Nature. 2020 Aug;584(7821):430-6. http://dx.doi.org/ 10.1038/s41586-020-2521-4. PubMed. 1476-4687

7. Bravi F, Flacco ME, Carradori T, Volta CA, Cosenza G, De Togni A, et al. Predictors of severe or lethal COVID-19, including Angiotensin Converting Enzyme inhibitors and Angiotensin II Receptor Blockers, in a sample of infected Italian citizens. PLoS One. 2020 Jun;15(6):e0235248. http://dx.doi.org/10.1371/journal.pone.0235248. PubMed. 1932-6203

8. Hothorn T, Bopp M, Günthard H, Keiser O, Roelens M, Weibull CE, et al. Assessing relative COVID-19 mortality: a Swiss population-based study. BMJ Open. 2021 Mar;11(3):e042387. http://dx.doi.org/10.1136 bmjopen-2020-042387. PubMed. 2044-6055

9. Maximiano Sousa F, Roelens M, Fricker B, Thiabaud A, Iten A, Cusini A, et al.; Ch-Sur Study Group. Risk factors for severe outcomes for COVID-19 patients hospitalised in Switzerland during the first pandemic wave, February to August 2020: prospective observational cohort study. Swiss Med Wkly. 2021 Jul;151:w20547. http://dx.doi.org/ 10.4414/smw.2021.20547. PubMed. 1424-3997

10. Dennis JM, McGovern AP, Vollmer SJ, Mateen BA. Improving Survival of Critical Care Patients With Coronavirus Disease 2019 in England: A National Cohort Study, March to June 2020. Crit Care Med. 2021 Feb;49(2):209-14. http://dx.doi.org/10.1097/ CCM.0000000000004747. PubMed. 1530-0293

11. Thiabaud A, Iten A, Balmelli C, Senn L, Troillet N, Widmer A, et al. Cohort profile: SARS-CoV-2/COVID-19 hospitalised patients in Switzerland. Swiss Med Wkly. 2021 Feb;151:w20475. [cited 2021 Mar 15] Available from: https://smw.ch/article/doi/smw.2021.20475 http://dx.doi.org/10.4414/smw.2021.20475. PubMed. 1424-3997

12. Hospital-based surveillance of COVID-19 in Switzerland. 2020. Available at: https://www.unige.ch/medecine/hospital-covid/. Accessed 2021 April 30.

13. Putter H, Fiocco M, Geskus RB. Tutorial in biostatistics: competing risks and multi-state models. Stat Med. 2007 May;26(11):2389-430. http://dx.doi.org/10.1002/sim.2712. PubMed. 0277-6715

14. Putter H. Tutorial in biostatistics: Competing risks and multi-state models Analyses using the mstate package. :43.
15. Fine JP, Gray RJ. A Proportional Hazards Model for the Subdistribution of a Competing Risk. J Am Stat Assoc. 1999;94(446):496-509. http://dx.doi.org/10.1080/01621459.1999.10474144. 0162-1459

16. Shepherd BE, Rebeiro PF; Caribbean, Central and South America network for HIV epidemiology. Assessing and interpreting the association between continuous covariates and outcomes in observational studies of HIV using splines. J Acquir Immune Defic Syndr. 2017 Mar;74(3):e60-3. http://dx.doi.org/10.1097/ QAI.0000000000001221. PubMed. 1944-7884

17. van Buuren S, Groothuis-Oudshoorn K. mice: Multivariate Imputation by Chained Equations in R. J Stat Softw. 2011;45(3):1-67. http://dx.doi.org/10.18637/jss.v045.i03. 1548-7660

18. Rochwerg B, Agarwal A, Siemieniuk RA, Agoritsas T, Lamontagne F, Askie L, et al. A living WHO guideline on drugs for covid-19. BMJ. 2020 Sep;370:m3379. http://dx.doi.org/10.1136/bmj.m3379. PubMed. 1756-1833

19. Horby P, Lim WS, Emberson JR, Mafham M, Bell JL, Linsell L, et al.; RECOVERY Collaborative Group. Dexamethasone in Hospitalized Patients with Covid-19. N Engl J Med. 2021 Feb;384(8):693-704. http://dx.doi.org/10.1056/NEJMoa2021436. PubMed. 1533-4406

20. SAMS - Swiss Academy of Medical Sciences. Intensive care medicine: triage under resource scarcity. Available at: https://www.samw.ch/en/ Ethics/Topics-A-to-Z/Intensive-care-medicine.html. Accessed 2021 July 27.

21. Synthèse des indicateurs de suivi de l'épidémie COVID-19 - data.gouv.fr. Available at: /fr/datasets/synthese-des-indicateurs-de-suivide-lepidemie-covid-19/. Accessed 2021 June 18.

22. Gessler N, Gunawardene MA, Wohlmuth P, Arnold D, Behr J, Gloeckner C, et al. Clinical outcome, risk assessment, and seasonal variation in hospitalized COVID-19 patients-Results from the CORONA Germany study. PLoS One. 2021 Jun;16(6):e0252867. http://dx.doi.org/10.1371/ journal.pone.0252867. PubMed. 1932-6203

23. World Health Organization (WHO). Global Health Observatory - Life expectancy at birth. Available at: https:/www.who.int/data/gho/data/indicators/indicator-details/GHO/life-expectancy-at-birth-(years). Accessed 2021 July 30.

24. EuroMOMO. The European monitoring of excess mortality for public health action (EuroMOMO) network. Available at: https://www.euromomo.eu/. Accessed 2021 June 17.

25. Société Suisse de Médecine Intensive (SSMI). Nouvelles recommandations de la SSMI sur l'oxygénothérapie pourles patients COVID-19. Available at: https://www.sgi-ssmi.ch/fr/covi19.html?file=files/Dateiverwaltung/COVID_19/Guidelines/IMSGCVCM_Neue\%20Empfehlungen_Sauerstoff_Covid-19_FR_201027_03.pdf. Accessed 2021 July 21.

26. Société Suisse de Médecine Intensive (SSMI). Recommandations pour l'admission en unité de soins intermédiaires et de soins intensifs des patients présentant une infection à SARS-CoV-2 -Epidémie Covid-19. Available at: https://www.sgi-ssmi.ch/fr/covi19.html?file=files/Dateiverwaltung/COVID_19/Guidelines/ISGCVCM_Triageempfehlungen 200318 FR.pdf

27. Colloque médical COVID-19|HUG - Hôpitaux Universitaires de Genève. Available at: https://www.hug.ch/maladies-infectieuses/colloque-medical-covid-19. Accessed 2021 May 7.

28. Recommandations pour les professionnels de la santé|HUG - Hôpitaux Universitaires de Genève. Available at: https://www.hug.ch/coronavirus/ recommandations-pour-professionnels-sante. Accessed 2021 June 18.

29. Calligaro GL, Lalla U, Audley G, Gina P, Miller MG, Mendelson M, et al. The utility of high-flow nasal oxygen for severe COVID-19 pneumonia in a resource-constrained setting: A multi-centre prospective observational study. EClinicalMedicine. 2020 Nov;28:100570. [cited 2021 Jun 17] Available from: https://www.thelancet.com/journals/eclinm/article/PIIS2589-5370(20)30314-X/abstract http://dx.doi.org/10.1016/ j.eclinm.2020.100570. PubMed. 2589-5370

30. Søgaard KK, Baettig V, Osthoff M, Marsch S, Leuzinger K, Schweitzer M, et al. Community-acquired and hospital-acquired respiratory tract infection and bloodstream infection in patients hospitalized with COVID-19 pneumonia. J Intensive Care. 2021 Jan;9(1):10. http://dx.doi.org/10.1186/s40560-021-00526-y. PubMed. 2052-0492

31. Ritchie H, Ortiz-Ospina E, Beltekian D, et al. Coronavirus Pandemic (COVID-19). Our World in Data 2020; Available at: https://ourworldindata.org/coronavirus. Accessed 2021 July 29.

32. COVID-19. Stringency Index. Available at: https://ourworldindata.org/ grapher/covid-stringency-index. Accessed 2021 July 29.

33. Hammer GP, du Prel JB, Blettner M. Avoiding bias in observational studies: part 8 in a series of articles on evaluation of scientific publications. Dtsch Arztebl Int. 2009 Oct;106(41):664-8. PubMed. 1866-0452

34. Tracking SARS-CoV-2 variants. Available at: https://www.who.int/activities/tracking-SARS-CoV-2-variants. Accessed 2021 June 24. 
35. Challen R, Brooks-Pollock E, Read JM, Dyson L, Tsaneva-Atanaso-va $\mathrm{K}$, Danon L. Risk of mortality in patients infected with SARS-CoV-2 variant of concern 202012/1: matched cohort study. BMJ. 2021 Mar;372(579):n579. http://dx.doi.org/10.1136/bmj.n579. PubMed. 1756-1833

36. Patone M, Thomas K, Hatch R, et al. Analysis of severe outcomes associated with the SARS-CoV-2 Variant of Concern 202012/01 in England using ICNARC Case Mix Programme and QResearch databases.
medRxiv 2021; 2021.03.11.21253364. http://dx.doi.org/10.1101/ 2021.03.11.21253364.

37. Sheikh A, McMenamin J, Taylor B, Robertson C; Public Health Scotland and the EAVE II Collaborators. SARS-CoV-2 Delta VOC in Scotland: demographics, risk of hospital admission, and vaccine effectiveness. Lancet. 2021 Jun;397(10293):2461-2. http://dx.doi.org/10.1016/ S0140-6736(21)01358-1. PubMed. 1474-547X 


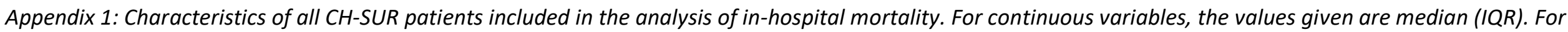

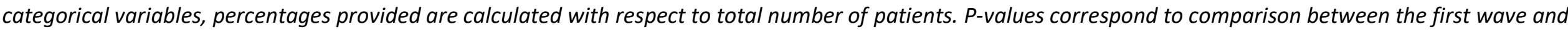
the second wave, from Kruskal-Wallis Rank-Sum test for continuous variables and Chi-Square test for categorical variables.

\begin{tabular}{|c|c|c|c|c|c|c|c|}
\hline & & $\begin{array}{l}\text { All } \\
N=16984\end{array}$ & $\begin{array}{l}\text { First wave } \\
\mathrm{N}=2808\end{array}$ & $\begin{array}{l}\text { Intermediate phase } \\
N=567\end{array}$ & $\begin{array}{l}\text { Second wave } \\
N=10653\end{array}$ & $\begin{array}{l}\text { Third wave } \\
\mathrm{N}=2956\end{array}$ & $\begin{array}{l}\text { P-value 1st } \\
\text { wave VS } 2 \text { nd } \\
\text { wave }\end{array}$ \\
\hline Outcome & $\begin{array}{l}\text { Censored } \\
\text { Deceased - } \\
\text { COVID19 } \\
\text { Deceased - other } \\
\text { Discharged } \\
\text { Transferred }\end{array}$ & $\begin{array}{l}638(3.8 \%) \\
2201(13 \%) \\
257(1.5 \%) \\
13386 \\
(78.8 \%) \\
502(3 \%) \\
\end{array}$ & $\begin{array}{l}2(0.1 \%) \\
438(15.6 \%) \\
12(0.4 \%) \\
2240 \\
(79.8 \%) \\
116(4.1 \%) \\
\end{array}$ & $\begin{array}{l}25(4.4 \%) \\
41(7.2 \%) \\
1(0.2 \%) \\
484(85.4 \%) \\
16(2.8 \%)\end{array}$ & $\begin{array}{l}440(4.1 \%) \\
1485(13.9 \%) \\
211(2 \%) \\
8216(77.1 \%) \\
301(2.8 \%)\end{array}$ & $\begin{array}{l}171(5.8 \%) \\
237(8 \%) \\
33(1.1 \%) \\
2446(82.7 \%) \\
69(2.3 \%)\end{array}$ & $P<0.001$ \\
\hline $\begin{array}{l}\text { Time from } \\
\text { diagnosis to } \\
\text { outcome or } \\
\text { censoring (d) }\end{array}$ & & $13(7-21)$ & $11(6-21)$ & $11(6-21)$ & $13(7-22)$ & $12(7-20)$ & $P<0.001$ \\
\hline $\begin{array}{l}\text { Time from } \\
\text { symptoms } \\
\text { onset to } \\
\text { diagnosis (d) }\end{array}$ & & $2(0-6)$ & $4(1-7)$ & $3(1-7)$ & $2(0-5)$ & $2(1-5)$ & $P<0.001$ \\
\hline $\begin{array}{l}\text { Time from } \\
\text { hospital } \\
\text { admission to } \\
\text { outcome (d) }\end{array}$ & & $9(5-19)$ & $10(5-20)$ & $9(5-19)$ & 10 (5 - 19) & $8(5-17)$ & $P=0.38$ \\
\hline $\begin{array}{l}\text { Time from } \\
\text { diagnosis to } \\
\text { hospital } \\
\text { admission (d) }\end{array}$ & & $0(0-4)$ & $0(0-2)$ & $0(0-2)$ & $0(0-4)$ & $0(0-6)$ & $P<0.001$ \\
\hline Age (years) & & $71(58-81)$ & $69(55-80)$ & $63(52.5-74)$ & $73(61-82)$ & $62(51-74)$ & $P<0.001$ \\
\hline
\end{tabular}




\begin{tabular}{|c|c|c|c|c|c|c|c|}
\hline & & $\begin{array}{l}\text { All } \\
N=16984\end{array}$ & $\begin{array}{l}\text { First wave } \\
N=2808\end{array}$ & $\begin{array}{l}\text { Intermediate phase } \\
N=567\end{array}$ & $\begin{array}{l}\text { Second wave } \\
N=10653\end{array}$ & $\begin{array}{l}\text { Third wave } \\
\mathrm{N}=2956\end{array}$ & $\begin{array}{l}\text { P-value 1st } \\
\text { wave VS 2nd } \\
\text { wave } \\
\end{array}$ \\
\hline Sex & $\begin{array}{l}\text { female } \\
\text { male }\end{array}$ & $\begin{array}{l}7187(42.3 \%) \\
9797(57.7 \%)\end{array}$ & $\begin{array}{l}1119 \\
(39.9 \%) \\
1689 \\
(60.1 \%)\end{array}$ & $\begin{array}{l}222(39.2 \%) \\
345(60.8 \%)\end{array}$ & $\begin{array}{l}4527(42.5 \%) \\
6126(57.5 \%)\end{array}$ & $\begin{array}{l}1319(44.6 \%) \\
1637(55.4 \%)\end{array}$ & $P=0.012$ \\
\hline Obesity & $\begin{array}{l}\text { no } \\
\text { yes } \\
\text { unknown }\end{array}$ & $\begin{array}{l}9195(54.1 \%) \\
4375(25.8 \%) \\
3414(20.1 \%)\end{array}$ & $\begin{array}{l}1377(49 \%) \\
619(22 \%) \\
812(28.9 \%)\end{array}$ & $\begin{array}{l}246(43.4 \%) \\
178(31.4 \%) \\
143(25.2 \%)\end{array}$ & $\begin{array}{l}5997(56.3 \%) \\
2707(25.4 \%) \\
1949(18.3 \%)\end{array}$ & $\begin{array}{l}1575(53.3 \%) \\
871(29.5 \%) \\
510(17.3 \%)\end{array}$ & $P<0.001$ \\
\hline Smoking & $\begin{array}{l}\text { no } \\
\text { yes } \\
\text { unknown }\end{array}$ & $\begin{array}{l}9192(54.1 \%) \\
1765(10.4 \%) \\
6027(35.5 \%)\end{array}$ & $\begin{array}{l}1671 \\
(59.5 \%) \\
235(8.4 \%) \\
902(32.1 \%)\end{array}$ & $\begin{array}{l}337(59.4 \%) \\
40(7.1 \%) \\
190(33.5 \%)\end{array}$ & $\begin{array}{l}5540(52 \%) \\
1111(10.4 \%) \\
4002(37.6 \%)\end{array}$ & $\begin{array}{l}1644(55.6 \%) \\
379(12.8 \%) \\
933(31.6 \%)\end{array}$ & $P<0.001$ \\
\hline Renal disease & $\begin{array}{l}\text { no } \\
\text { yes } \\
\text { unknown }\end{array}$ & $\begin{array}{l}13326 \\
(78.5 \%) \\
3207(18.9 \%) \\
451(2.7 \%) \\
\end{array}$ & $\begin{array}{l}2338 \\
(83.3 \%) \\
466(16.6 \%) \\
4(0.1 \%) \\
\end{array}$ & $\begin{array}{l}466(82.2 \%) \\
79(13.9 \%) \\
22(3.9 \%)\end{array}$ & $\begin{array}{l}7962(74.7 \%) \\
2304(21.6 \%) \\
387(3.6 \%)\end{array}$ & $\begin{array}{l}2560(86.6 \%) \\
358(12.1 \%) \\
38(1.3 \%)\end{array}$ & $P<0.001$ \\
\hline $\begin{array}{l}\text { Oncological } \\
\text { pathology }\end{array}$ & $\begin{array}{l}\text { no } \\
\text { yes } \\
\text { unknown }\end{array}$ & $\begin{array}{l}14489 \\
(85.3 \%) \\
2030(12 \%) \\
465(2.7 \%) \\
\end{array}$ & $\begin{array}{l}2513 \\
(89.5 \%) \\
290(10.3 \%) \\
5(0.2 \%) \\
\end{array}$ & $\begin{array}{l}472(83.2 \%) \\
71(12.5 \%) \\
24(4.2 \%)\end{array}$ & $\begin{array}{l}8841(83 \%) \\
1417(13.3 \%) \\
395(3.7 \%)\end{array}$ & $\begin{array}{l}2663(90.1 \%) \\
252(8.5 \%) \\
41(1.4 \%)\end{array}$ & $P<0.001$ \\
\hline \begin{tabular}{|l} 
Chronic \\
respiratory \\
disease
\end{tabular} & $\begin{array}{l}\text { no } \\
\text { yes } \\
\text { unknown }\end{array}$ & $\begin{array}{l}13224 \\
(77.9 \%) \\
3310(19.5 \%) \\
450(2.6 \%)\end{array}$ & $\begin{array}{l}2189(78 \%) \\
613(21.8 \%) \\
6(0.2 \%)\end{array}$ & $\begin{array}{l}442(78 \%) \\
103(18.2 \%) \\
22(3.9 \%)\end{array}$ & $\begin{array}{l}8153(76.5 \%) \\
2116(19.9 \%) \\
384(3.6 \%)\end{array}$ & $\begin{array}{l}2440(82.5 \%) \\
478(16.2 \%) \\
38(1.3 \%)\end{array}$ & $P<0.001$ \\
\hline $\begin{array}{l}\text { Cardiovascular } \\
\text { disease }\end{array}$ & $\begin{array}{l}\text { no } \\
\text { yes } \\
\text { unknown }\end{array}$ & $\begin{array}{l}10811 \\
(63.7 \%) \\
5730(33.7 \%) \\
443(2.6 \%)\end{array}$ & $\begin{array}{l}1925 \\
(68.6 \%) \\
883(31.4 \%) \\
0(0 \%)\end{array}$ & $\begin{array}{l}391(69 \%) \\
153(27 \%) \\
23(4.1 \%)\end{array}$ & $\begin{array}{l}6271(58.9 \%) \\
4006(37.6 \%) \\
376(3.5 \%)\end{array}$ & $\begin{array}{l}2224(75.2 \%) \\
688(23.3 \%) \\
44(1.5 \%)\end{array}$ & $P<0.001$ \\
\hline
\end{tabular}




\begin{tabular}{|c|c|c|c|c|c|c|c|}
\hline & & $\begin{array}{l}\text { All } \\
N=16984\end{array}$ & $\begin{array}{l}\text { First wave } \\
\mathrm{N}=2808\end{array}$ & $\begin{array}{l}\text { Intermediate phase } \\
N=567\end{array}$ & $\begin{array}{l}\text { Second wave } \\
N=10653\end{array}$ & $\begin{array}{l}\text { Third wave } \\
\mathrm{N}=2956\end{array}$ & $\begin{array}{l}\text { P-value 1st } \\
\text { wave VS } 2 \text { nd } \\
\text { wave }\end{array}$ \\
\hline Dementia & $\begin{array}{l}\text { no } \\
\text { yes } \\
\text { unknown }\end{array}$ & $\begin{array}{l}15045 \\
(88.6 \%) \\
1461(8.6 \%) \\
478(2.8 \%)\end{array}$ & $\begin{array}{l}2609 \\
(92.9 \%) \\
190(6.8 \%) \\
9(0.3 \%)\end{array}$ & $\begin{array}{l}497(87.7 \%) \\
46(8.1 \%) \\
24(4.2 \%)\end{array}$ & $\begin{array}{l}9132(85.7 \%) \\
1117(10.5 \%) \\
404(3.8 \%)\end{array}$ & $\begin{array}{l}2807(95 \%) \\
108(3.7 \%) \\
41(1.4 \%)\end{array}$ & $P<0.001$ \\
\hline $\begin{array}{l}\text { Immuno- } \\
\text { suppression }\end{array}$ & $\begin{array}{l}\text { no } \\
\text { yes } \\
\text { unknown } \\
\end{array}$ & $\begin{array}{l}15118(89 \%) \\
1371(8.1 \%) \\
495(2.9 \%) \\
\end{array}$ & $\begin{array}{l}2556(91 \%) \\
217(7.7 \%) \\
35(1.2 \%) \\
\end{array}$ & $\begin{array}{l}508(89.6 \%) \\
36(6.3 \%) \\
23(4.1 \%) \\
\end{array}$ & $\begin{array}{l}9345(87.7 \%) \\
912(8.6 \%) \\
396(3.7 \%) \\
\end{array}$ & $\begin{array}{l}2709(91.6 \%) \\
206(7 \%) \\
41(1.4 \%) \\
\end{array}$ & $P<0.001$ \\
\hline $\begin{array}{l}\text { Any } \\
\text { comorbidity }\end{array}$ & $\begin{array}{l}\text { no } \\
\text { yes } \\
\text { unknown }\end{array}$ & $\begin{array}{l}2832(16.7 \%) \\
13746 \\
(80.9 \%) \\
406(2.4 \%)\end{array}$ & $\begin{array}{l}577(20.5 \%) \\
2231 \\
(79.5 \%) \\
0(0 \%)\end{array}$ & $\begin{array}{l}103(18.2 \%) \\
442(78 \%) \\
22(3.9 \%)\end{array}$ & $\begin{array}{l}1385(13 \%) \\
8910(83.6 \%) \\
358(3.4 \%)\end{array}$ & $\begin{array}{l}767(25.9 \%) \\
2163(73.2 \%) \\
26(0.9 \%)\end{array}$ & $P<0.001$ \\
\hline CURB-65 score & $\begin{array}{l}0 \\
1 \\
2 \\
3 \\
4 \\
5 \\
\text { unknown }\end{array}$ & $\begin{array}{l}4441(26.1 \%) \\
6214(36.6 \%) \\
4405(25.9 \%) \\
1568(9.2 \%) \\
320(1.9 \%) \\
33(0.2 \%) \\
3(0 \%)\end{array}$ & $\begin{array}{l}870(31 \%) \\
940(33.5 \%) \\
672(23.9 \%) \\
268(9.5 \%) \\
53(1.9 \%) \\
5(0.2 \%) \\
0(0 \%)\end{array}$ & $\begin{array}{l}214(37.7 \%) \\
196(34.6 \%) \\
113(19.9 \%) \\
39(6.9 \%) \\
4(0.7 \%) \\
1(0.2 \%) \\
0(0 \%)\end{array}$ & $\begin{array}{l}2230(20.9 \%) \\
4011(37.7 \%) \\
3089(29 \%) \\
1078(10.1 \%) \\
222(2.1 \%) \\
22(0.2 \%) \\
1(0 \%)\end{array}$ & $\begin{array}{l}1127(38.1 \%) \\
1067(36.1 \%) \\
531(18 \%) \\
183(6.2 \%) \\
41(1.4 \%) \\
5(0.2 \%) \\
2(0.1 \%) \\
\end{array}$ & $P<0.001$ \\
\hline $\begin{array}{l}\text { Ever admitted } \\
\text { to ICU }\end{array}$ & $\begin{array}{l}\text { no } \\
\text { yes } \\
\text { unknown }\end{array}$ & $\begin{array}{l}13752(81 \%) \\
2723(16 \%) \\
509(3 \%)\end{array}$ & $\begin{array}{l}2272 \\
(80.9 \%) \\
534(19 \%) \\
2(0.1 \%)\end{array}$ & $\begin{array}{l}434(76.5 \%) \\
111(19.6 \%) \\
22(3.9 \%)\end{array}$ & $\begin{array}{l}8715(81.8 \%) \\
1576(14.8 \%) \\
362(3.4 \%)\end{array}$ & $\begin{array}{l}2331(78.9 \%) \\
502(17 \%) \\
123(4.2 \%)\end{array}$ & $P<0.001$ \\
\hline $\begin{array}{l}\text { Ever admitted } \\
\text { to IMCU/ICU }\end{array}$ & $\begin{array}{l}\text { no } \\
\text { yes } \\
\text { unknown }\end{array}$ & $\begin{array}{l}12742(75 \%) \\
3750(22.1 \%) \\
492(2.9 \%)\end{array}$ & $\begin{array}{l}1988 \\
(70.8 \%) \\
819(29.2 \%) \\
1(0 \%)\end{array}$ & $\begin{array}{l}399(70.4 \%) \\
146(25.7 \%) \\
22(3.9 \%)\end{array}$ & $\begin{array}{l}8179(76.8 \%) \\
2112(19.8 \%) \\
362(3.4 \%)\end{array}$ & $\begin{array}{l}2176(73.6 \%) \\
673(22.8 \%) \\
107(3.6 \%)\end{array}$ & $P<0.001$ \\
\hline
\end{tabular}


Appendix 2: Median and IQR of time from first COVID-19 diagnosis to outcome (or censoring), stratified by time period and by outcome, for hospitalised patients

\begin{tabular}{|lllllll|}
\hline Outcome & & Censored & $\begin{array}{l}\text { Deceased }- \\
\text { COVID-19 }\end{array}$ & Deceased - other Discharged & Transferred \\
\hline All periods & $\mathrm{N}$ & 638 & 2201 & 257 & 13386 & 502 \\
& $\mathrm{t}$ & $263.5(141.75-283)$ & $11(6-19)$ & $15(7-34)$ & $12(7-20)$ & $11(3-21)$ \\
First wave & $\mathrm{N}$ & 2 & 438 & 12 & 2240 & 116 \\
& $\mathrm{t}$ & $508(506-510)$ & $9(6-15)$ & $12(7-45.25)$ & $12(7-23)$ & $11(2.75-21)$ \\
Intermediate & $\mathrm{N}$ & 25 & 41 & 1 & 484 & 16 \\
phase & $\mathrm{t}$ & $331(324-342)$ & $18(7-27)$ & $1(1-1)$ & $10(6-18)$ & $15.5(9.75-19.5)$ \\
& $\mathrm{N}$ & 440 & 1485 & 211 & 8216 & 301 \\
Second wave & $\mathrm{t}$ & $274(254.75-286)$ & $12(6-20)$ & $16(7.5-37)$ & $13(7-20)$ & $11(3-21)$ \\
& $\mathrm{N}$ & 171 & 237 & 33 & 2446 & 69 \\
Third wave & $\mathrm{t}$ & $98(85-112)$ & $12(7-23)$ & $10(5-19)$ & $12(7-17)$ & $14(6-25)$ \\
\hline
\end{tabular}


Appendix 3: Cumulative incidence functions for discharge (upper left), transfer (upper right) and death due to other cause than COVID-19 (bottom) for the waves of COVID-19.
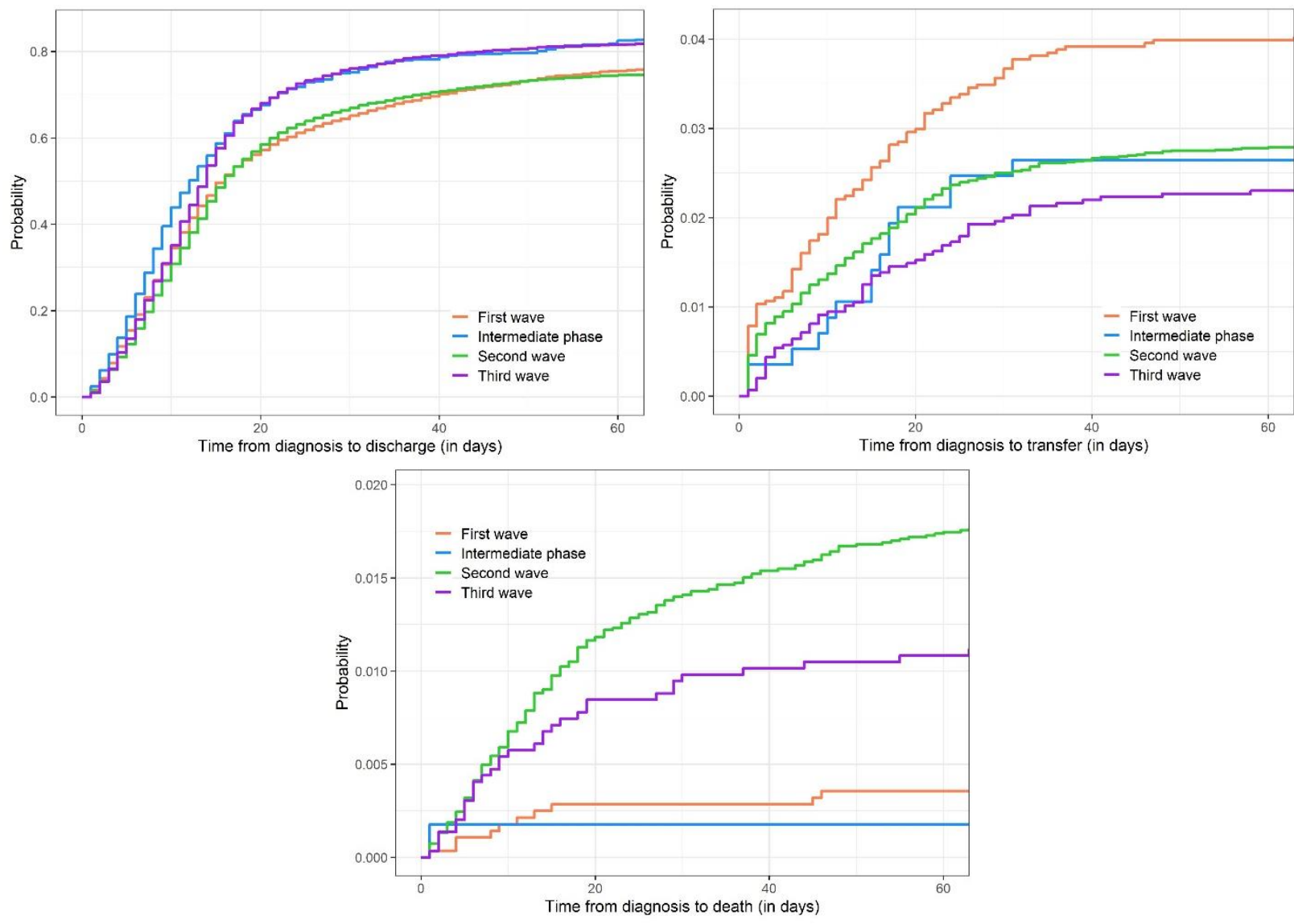
Appendix 4: Hazard ratios for death due to COVID-19 among hospitalised patients, from the multivariable Fine and Gray model with imputation of missing variables, multivariable Fine and Gray model on complete cases, and univariable Fine and Gray model on complete cases.

\begin{tabular}{|c|c|c|c|c|}
\hline & & Multivariable, imputed & $\begin{array}{l}\text { Multivariable, complete } \\
\text { cases }\end{array}$ & $\begin{array}{l}\text { Univariable,complete } \\
\text { cases }\end{array}$ \\
\hline \multirow[t]{5}{*}{ Age (years) } & & $P<0.001$ & $P<0.001$ & $P<0.001$ \\
\hline & 35 & $0.0662(0.0433-0.101)$ & $0.0568(0.0305-0.106)$ & $0.043(0.0279-0.0662)$ \\
\hline & 50 & $0.279(0.232-0.335)$ & $0.259(0.198-0.34)$ & $0.23(0.191-0.278)$ \\
\hline & 65 & 1.0 (ref) & 1.0 (ref) & 1.0 (ref) \\
\hline & 80 & $2.31(2.16-2.48)$ & $2.34(2.12-2.58)$ & $2.43(2.29-2.58)$ \\
\hline \multirow[t]{3}{*}{ Sex } & & $P<0.001$ & $P<0.001$ & $P<0.001$ \\
\hline & Female & 1.0 (ref) & 1.0 (ref) & 1.0 (ref) \\
\hline & Male & $1.54(1.41-1.69)$ & $1.71(1.5-1.95)$ & $1.42(1.3-1.55)$ \\
\hline \multirow[t]{3}{*}{ Obesity } & & $P=0.011$ & $P=0.004$ & $P<0.001$ \\
\hline & No & 1.0 (ref) & 1.0 (ref) & 1.0 (ref) \\
\hline & Yes & $1.16(1.03-1.3)$ & $1.22(1.07-1.4)$ & $0.82(0.739-0.91)$ \\
\hline \multirow[t]{3}{*}{ Smoking } & & $P=0.56$ & $P=0.55$ & $P=0.43$ \\
\hline & No & 1.0 (ref) & 1.0 (ref) & 1.0 (ref) \\
\hline & Yes & $1.05(0.895-1.23)$ & $1.05(0.893-1.24)$ & $1.06(0.919-1.22)$ \\
\hline \multirow[t]{3}{*}{ Renal disease } & & $P<0.001$ & $P<0.001$ & $P<0.001$ \\
\hline & No & 1.0 (ref) & 1.0 (ref) & 1.0 (ref) \\
\hline & Yes & $1.41(1.29-1.55)$ & $1.39(1.22-1.58)$ & $2.68(2.46-2.93)$ \\
\hline \multirow{3}{*}{$\begin{array}{l}\text { Oncological } \\
\text { pathology }\end{array}$} & & $P<0.001$ & $P<0.001$ & $P<0.001$ \\
\hline & No & 1.0 (ref) & 1.0 (ref) & 1.0 (ref) \\
\hline & Yes & $1.34(1.2-1.49)$ & $1.4(1.22-1.62)$ & $1.98(1.78-2.19)$ \\
\hline \multirow{3}{*}{$\begin{array}{l}\text { Chronic } \\
\text { respiratory } \\
\text { disease }\end{array}$} & & $P<0.001$ & $P<0.001$ & $P<0.001$ \\
\hline & No & 1.0 (ref) & 1.0 (ref) & 1.0 (ref) \\
\hline & Yes & $1.26(1.14-1.39)$ & $1.33(1.17-1.51)$ & $1.58(1.44-1.74)$ \\
\hline \multirow{3}{*}{$\begin{array}{l}\text { Cardiovascular } \\
\text { disease }\end{array}$} & & $P<0.001$ & $P=0.0067$ & $P<0.001$ \\
\hline & No & 1.0 (ref) & 1.0 (ref) & 1.0 (ref) \\
\hline & Yes & $1.24(1.13-1.36)$ & $1.2(1.05-1.36)$ & $2.69(2.47-2.92)$ \\
\hline \multirow[t]{3}{*}{ Dementia } & & $P=0.16$ & $P=0.17$ & $P<0.001$ \\
\hline & No & 1.0 (ref) & 1.0 (ref) & 1.0 (ref) \\
\hline & Yes & $1.09(0.965-1.23)$ & $1.13(0.949-1.34)$ & $2.07(1.85-2.33)$ \\
\hline \multirow{3}{*}{$\begin{array}{l}\text { Immuno- } \\
\text { suppression }\end{array}$} & & $P<0.001$ & $P<0.001$ & $P<0.001$ \\
\hline & No & 1.0 (ref) & 1.0 (ref) & 1.0 (ref) \\
\hline & Yes & $1.5(1.32-1.71)$ & $1.43(1.2-1.71)$ & $1.69(1.5-1.92)$ \\
\hline \multirow[t]{5}{*}{ Time period } & First wave & $P<0.001$ & $P<0.001$ & $P<0.001$ \\
\hline & Intermediate & 1.0 (ref) & 1.0 (ref) & 1.0 (ref) \\
\hline & & $0.495(0.359-0.682)$ & $0.666(0.449-0.989)$ & $0.439(0.319-0.604)$ \\
\hline & Second wave & $0.7(0.629-0.779)$ & $0.729(0.625-0.849)$ & $0.876(0.788-0.975)$ \\
\hline & Third wave & $0.645(0.55-0.756)$ & $0.667(0.535-0.832)$ & $0.488(0.417-0.572)$ \\
\hline
\end{tabular}


Appendix 5: Hazard ratios for death due to COVID-19 among hospitalised patients, from the multivariable Cox model with imputation of missing variables, multivariable Cox model on complete cases, and univariable Cox model on complete cases.

\begin{tabular}{|c|c|c|c|c|}
\hline & & $\begin{array}{l}\text { Multivariable, } \\
\text { imputed }\end{array}$ & $\begin{array}{l}\text { Multivariable, complete } \\
\text { cases }\end{array}$ & $\begin{array}{l}\text { Univariable,complete } \\
\text { cases }\end{array}$ \\
\hline \multirow[t]{5}{*}{ Age (years) } & & $P<0.001$ & $P<0.001$ & $P<0.001$ \\
\hline & 35 & $0.096(0.0647-0.142)$ & $0.0875(0.0486-0.158)$ & $0.0666(0.0448-0.099)$ \\
\hline & 50 & $0.326(0.273-0.389)$ & $0.314(0.241-0.409)$ & $0.277(0.232-0.331)$ \\
\hline & 65 & 1.0 (ref) & 1.0 (ref) & 1.0 (ref) \\
\hline & 80 & $2.13(1.99-2.29)$ & $2.1(1.9-2.32)$ & $2.19(2.06-2.33)$ \\
\hline \multirow[t]{3}{*}{ Sex } & & $P<0.001$ & $P<0.001$ & $P<0.001$ \\
\hline & Female & 1.0 (ref) & 1.0 (ref) & 1.0 (ref) \\
\hline & Male & $1.48(1.35-1.62)$ & $1.62(1.42-1.85)$ & $1.35(1.23-1.47)$ \\
\hline \multirow[t]{3}{*}{ Obesity } & & $P=0.0031$ & $P=0.0029$ & $P=0.012$ \\
\hline & No & 1.0 (ref) & 1.0 (ref) & 1.0 (ref) \\
\hline & Yes & $1.19(1.06-1.34)$ & $1.23(1.07-1.41)$ & $0.875(0.788-0.971)$ \\
\hline \multirow[t]{3}{*}{ Smoking } & & $P=0.35$ & $P=0.1$ & $P=0.46$ \\
\hline & No & 1.0 (ref) & 1.0 (ref) & 1.0 (ref) \\
\hline & Yes & $1.08(0.919-1.27)$ & $1.15(0.974-1.35)$ & $1.05(0.916-1.21)$ \\
\hline \multirow[t]{3}{*}{ Renal disease } & & $P<0.001$ & $P<0.001$ & $P<0.001$ \\
\hline & No & 1.0 (ref) & 1.0 (ref) & 1.0 (ref) \\
\hline & Yes & $1.41(1.28-1.56)$ & $1.38(1.21-1.57)$ & $2.31(2.12-2.52)$ \\
\hline \multirow{3}{*}{$\begin{array}{l}\text { Oncological } \\
\text { pathology }\end{array}$} & & $P<0.001$ & $P<0.001$ & $P<0.001$ \\
\hline & No & 1.0 (ref) & 1.0 (ref) & 1.0 (ref) \\
\hline & Yes & $1.31(1.17-1.47)$ & $1.35(1.17-1.56)$ & $1.74(1.57-1.93)$ \\
\hline \multirow{3}{*}{$\begin{array}{l}\text { Chronic } \\
\text { respiratory } \\
\text { disease }\end{array}$} & & $P=0.017$ & $P=0.0041$ & $P<0.001$ \\
\hline & No & 1.0 (ref) & 1.0 (ref) & 1.0 (ref) \\
\hline & Yes & $1.14(1.02-1.27)$ & $1.21(1.06-1.38)$ & $1.38(1.25-1.51)$ \\
\hline \multirow{3}{*}{$\begin{array}{l}\text { Cardiovascular } \\
\text { disease }\end{array}$} & & $P<0.001$ & $P=0.012$ & $P<0.001$ \\
\hline & No & 1.0 (ref) & 1.0 (ref) & 1.0 (ref) \\
\hline & Yes & $1.18(1.08-1.3)$ & $1.18(1.04-1.35)$ & $2.23(2.05-2.43)$ \\
\hline \multirow[t]{3}{*}{ Dementia } & & $P=0.51$ & $P=0.67$ & $P<0.001$ \\
\hline & No & 1.0 (ref) & 1.0 (ref) & 1.0 (ref) \\
\hline & Yes & $0.959(0.846-1.09)$ & $0.963(0.811-1.14)$ & $1.59(1.42-1.79)$ \\
\hline \multirow{3}{*}{$\begin{array}{l}\text { Immuno- } \\
\text { suppression }\end{array}$} & & $P<0.001$ & $P<0.001$ & $P<0.001$ \\
\hline & No & 1.0 (ref) & 1.0 (ref) & 1.0 (ref) \\
\hline & Yes & $1.4(1.23-1.6)$ & $1.39(1.16-1.66)$ & $1.48(1.31-1.68)$ \\
\hline \multirow[t]{5}{*}{ Time period } & & $P<0.001$ & $P=0.24$ & $P<0.001$ \\
\hline & First wave & 1.0 (ref) & 1.0 (ref) & 1.0 (ref) \\
\hline & Intermediate phase & $0.538(0.39-0.741)$ & $0.774(0.521-1.15)$ & $0.461(0.335-0.635)$ \\
\hline & Second wave & $0.756(0.679-0.843)$ & $0.891(0.764-1.04)$ & $0.834(0.75-0.928)$ \\
\hline & Third wave & $0.716(0.61-0.84)$ & $0.815(0.653-1.02)$ & $0.505(0.432-0.592)$ \\
\hline
\end{tabular}


Appendix 6: Same as Appendix 4 for in-hospital all-cause mortality within CH-SUR.

\begin{tabular}{|c|c|c|c|c|}
\hline & & Multivariable, imputed & $\begin{array}{l}\text { Multivariable, complete } \\
\text { cases }\end{array}$ & $\begin{array}{l}\text { Univariable,complete } \\
\text { cases }\end{array}$ \\
\hline \multirow[t]{5}{*}{ Age (years) } & & $P<0.001$ & $P<0.001$ & $P<0.001$ \\
\hline & 35 & $0.0797(0.0542-0.117)$ & $0.0689(0.0393-0.121)$ & $0.0501(0.0339-0.0742)$ \\
\hline & 50 & $0.303(0.257-0.358)$ & $0.283(0.221-0.362)$ & $0.247(0.208-0.292)$ \\
\hline & 65 & 1.0 (ref) & 1.0 (ref) & 1.0 (ref) \\
\hline & 80 & $2.23(2.09-2.38)$ & $2.25(2.05-2.47)$ & $2.38(2.25-2.52)$ \\
\hline \multirow[t]{3}{*}{ Sex } & & $P<0.001$ & $P<0.001$ & $P<0.001$ \\
\hline & Female & $1.0($ ref) & 1.0 (ref) & 1.0 (ref) \\
\hline & Male & $1.56(1.43-1.7)$ & $1.72(1.52-1.95)$ & $1.44(1.33-1.57)$ \\
\hline \multirow[t]{3}{*}{ Obesity } & & $P=0.054$ & $P=0.032$ & $P<0.001$ \\
\hline & No & 1.0 (ref) & 1.0 (ref) & 1.0 (ref) \\
\hline & Yes & $1.11(0.998-1.23)$ & $1.15(1.01-1.31)$ & $0.785(0.71-0.867)$ \\
\hline \multirow[t]{3}{*}{ Smoking } & & $P=0.47$ & $P=0.42$ & $P=0.2$ \\
\hline & No & 1.0 (ref) & 1.0 (ref) & 1.0 (ref) \\
\hline & Yes & $1.06(0.909-1.23)$ & $1.06(0.914-1.24)$ & $1.09(0.956-1.24)$ \\
\hline \multirow[t]{3}{*}{ Renal disease } & & $P<0.001$ & $P<0.001$ & $P<0.001$ \\
\hline & No & 1.0 (ref) & 1.0 (ref) & 1.0 (ref) \\
\hline & Yes & $1.41(1.28-1.54)$ & $1.41(1.25-1.6)$ & $2.68(2.46-2.91)$ \\
\hline \multirow{3}{*}{$\begin{array}{l}\text { Oncological } \\
\text { pathology }\end{array}$} & & $P<0.001$ & $P<0.001$ & $P<0.001$ \\
\hline & No & 1.0 (ref) & 1.0 (ref) & 1.0 (ref) \\
\hline & Yes & $1.51(1.37-1.67)$ & $1.63(1.43-1.86)$ & $2.24(2.03-2.46)$ \\
\hline \multirow{3}{*}{$\begin{array}{l}\text { Chronic } \\
\text { respiratory } \\
\text { disease }\end{array}$} & & $P<0.001$ & $P<0.001$ & $P<0.001$ \\
\hline & No & 1.0 (ref) & 1.0 (ref) & 1.0 (ref) \\
\hline & Yes & $1.26(1.15-1.39)$ & $1.34(1.19-1.52)$ & $1.58(1.45-1.73)$ \\
\hline \multirow{3}{*}{$\begin{array}{l}\text { Cardiovascular } \\
\text { disease }\end{array}$} & & $P<0.001$ & $P=0.0058$ & $P<0.001$ \\
\hline & No & 1.0 (ref) & 1.0 (ref) & 1.0 (ref) \\
\hline & Yes & $1.23(1.13-1.34)$ & $1.19(1.05-1.34)$ & $2.67(2.46-2.89)$ \\
\hline \multirow[t]{3}{*}{ Dementia } & & $P=0.026$ & $P=0.05$ & $P<0.001$ \\
\hline & No & 1.0 (ref) & 1.0 (ref) & 1.0 (ref) \\
\hline & Yes & $1.14(1.02-1.28)$ & $1.17(1-1.38)$ & $2.16(1.93-2.4)$ \\
\hline \multirow{3}{*}{$\begin{array}{l}\text { Immuno- } \\
\text { suppression }\end{array}$} & & $P<0.001$ & $P<0.001$ & $P<0.001$ \\
\hline & No & 1.0 (ref) & 1.0 (ref) & 1.0 (ref) \\
\hline & Yes & $1.49(1.32-1.68)$ & $1.38(1.17-1.64)$ & $1.7(1.51-1.92)$ \\
\hline \multirow[t]{5}{*}{ Time period } & & $P<0.001$ & $P=0.0039$ & $P<0.001$ \\
\hline & First wave & 1.0 (ref) & 1.0 (ref) & 1.0 (ref) \\
\hline & Intermediate & $0.486(0.354-0.667)$ & $0.629(0.424-0.932)$ & $0.44(0.322-0.603)$ \\
\hline & phase & $0.786(0.708-0.873)$ & $0.809(0.698-0.938)$ & $0.98(0.884-1.09)$ \\
\hline & $\begin{array}{l}\text { Second wave } \\
\text { Third wave }\end{array}$ & $0.723(0.621-0.841)$ & $0.716(0.579-0.885)$ & $0.543(0.467-0.632)$ \\
\hline
\end{tabular}




\begin{tabular}{|c|c|c|c|c|}
\hline & & $\begin{array}{l}\text { Multivariable, } \\
\text { imputed }\end{array}$ & $\begin{array}{l}\text { Multivariable, complete } \\
\text { cases }\end{array}$ & $\begin{array}{l}\text { Univariable,complete } \\
\text { cases }\end{array}$ \\
\hline \multirow[t]{5}{*}{ Age (years) } & & $P<0.001$ & $P<0.001$ & $P<0.001$ \\
\hline & 35 & $0.113(0.079-0.162)$ & $0.105(0.0614-0.178)$ & $0.0768(0.0536-0.11)$ \\
\hline & 50 & $0.352(0.3-0.414)$ & $0.342(0.269-0.434)$ & $0.296(0.252-0.348)$ \\
\hline & 65 & 1.0 (ref) & 1.0 (ref) & 1.0 (ref) \\
\hline & 80 & $2.04(1.91-2.18)$ & $2.01(1.83-2.21)$ & $2.12(2-2.24)$ \\
\hline \multirow[t]{3}{*}{ Sex } & & $P<0.001$ & $P<0.001$ & $P<0.001$ \\
\hline & Female & 1.0 (ref) & 1.0 (ref) & 1.0 (ref) \\
\hline & Male & $1.48(1.35-1.61)$ & $1.61(1.42-1.82)$ & $1.36(1.25-1.48)$ \\
\hline \multirow[t]{3}{*}{ Obesity } & & $P=0.014$ & $P=0.021$ & $P<0.001$ \\
\hline & No & 1.0 (ref) & 1.0 (ref) & 1.0 (ref) \\
\hline & Yes & $1.14(1.03-1.28)$ & $1.16(1.02-1.33)$ & $0.843(0.764-0.931)$ \\
\hline \multirow[t]{3}{*}{ Smoking } & & $P=0.3$ & $P=0.05$ & $P=0.25$ \\
\hline & No & 1.0 (ref) & 1.0 (ref) & 1.0 (ref) \\
\hline & Yes & $1.09(0.929-1.27)$ & $1.16(1-1.35)$ & $1.08(0.947-1.23)$ \\
\hline \multirow[t]{3}{*}{ Renal disease } & & $P<0.001$ & $P<0.001$ & $P<0.001$ \\
\hline & No & 1.0 (ref) & 1.0 (ref) & 1.0 (ref) \\
\hline & Yes & $1.41(1.28-1.55)$ & $1.4(1.24-1.58)$ & $2.29(2.1-2.48)$ \\
\hline \multirow{3}{*}{$\begin{array}{l}\text { Oncological } \\
\text { pathology }\end{array}$} & & $P<0.001$ & $P<0.001$ & $P<0.001$ \\
\hline & No & 1.0 (ref) & 1.0 (ref) & 1.0 (ref) \\
\hline & Yes & $1.47(1.32-1.64)$ & $1.53(1.35-1.75)$ & $1.94(1.76-2.13)$ \\
\hline \multirow{3}{*}{$\begin{array}{l}\text { Chronic } \\
\text { respiratory } \\
\text { disease }\end{array}$} & & $P=0.016$ & $P=0.0017$ & $P<0.001$ \\
\hline & No & 1.0 (ref) & 1.0 (ref) & 1.0 (ref) \\
\hline & Yes & $1.14(1.02-1.26)$ & $1.22(1.08-1.37)$ & $1.37(1.25-1.5)$ \\
\hline \multirow{3}{*}{$\begin{array}{l}\text { Cardiovascular } \\
\text { disease }\end{array}$} & & $P<0.001$ & $P=0.0092$ & $P<0.001$ \\
\hline & No & 1.0 (ref) & 1.0 (ref) & 1.0 (ref) \\
\hline & Yes & $1.17(1.07-1.28)$ & $1.18(1.04-1.33)$ & $2.19(2.02-2.37)$ \\
\hline \multirow[t]{3}{*}{ Dementia } & & $P=0.89$ & $P=0.86$ & $P<0.001$ \\
\hline & No & 1.0 (ref) & 1.0 (ref) & 1.0 (ref) \\
\hline & Yes & $0.992(0.88-1.12)$ & $0.986(0.84-1.16)$ & $1.63(1.46-1.81)$ \\
\hline \multirow{3}{*}{$\begin{array}{l}\text { Immuno- } \\
\text { suppression }\end{array}$} & & $P<0.001$ & $P<0.001$ & $P<0.001$ \\
\hline & No & 1.0 (ref) & 1.0 (ref) & 1.0 (ref) \\
\hline & Yes & $1.39(1.22-1.57)$ & $1.35(1.14-1.6)$ & $1.49(1.33-1.68)$ \\
\hline \multirow[t]{5}{*}{ Time period } & & $P<0.001$ & $P=0.27$ & $P<0.001$ \\
\hline & First wave & 1.0 (ref) & 1.0 (ref) & 1.0 (ref) \\
\hline & Intermediate phase & $0.525(0.382-0.721)$ & $0.745(0.502-1.11)$ & $0.458(0.334-0.627)$ \\
\hline & Second wave & $0.834(0.75-0.926)$ & $0.992(0.854-1.15)$ & $0.921(0.83-1.02)$ \\
\hline & Third wave & $0.788(0.676-0.919)$ & $0.878(0.709-1.09)$ & $0.559(0.481-0.651)$ \\
\hline
\end{tabular}




\begin{tabular}{|c|c|c|c|c|c|c|c|}
\hline & & $\begin{array}{l}\text { All } \\
N=3739\end{array}$ & $\begin{array}{l}\text { First wave } \\
N=819\end{array}$ & $\begin{array}{l}\text { Intermediate phase } \\
\mathrm{N}=145\end{array}$ & $\begin{array}{l}\text { Second wave } \\
N=2106\end{array}$ & $\begin{array}{l}\text { Third wave } \\
\mathrm{N}=669\end{array}$ & $\begin{array}{l}\text { P-value 1st } \\
\text { wave/2nd wave }\end{array}$ \\
\hline Outcome & $\begin{array}{l}\text { Censored } \\
\text { Deceased - COVID-19 } \\
\text { Deceased - other } \\
\text { Discharged } \\
\text { Transferred }\end{array}$ & $\begin{array}{l}102(2.7 \%) \\
896(24 \%) \\
81(2.2 \%) \\
2391(63.9 \%) \\
269(7.2 \%)\end{array}$ & $\begin{array}{l}1(0.1 \%) \\
158(19.3 \%) \\
8(1 \%) \\
586(71.6 \%) \\
66(8.1 \%)\end{array}$ & $\begin{array}{l}2(1.4 \%) \\
23(15.9 \%) \\
1(0.7 \%) \\
103(71 \%) \\
16(11 \%)\end{array}$ & $\begin{array}{l}45(2.1 \%) \\
577(27.4 \%) \\
59(2.8 \%) \\
1289(61.2 \%) \\
136(6.5 \%)\end{array}$ & $\begin{array}{l}54(8.1 \%) \\
138(20.6 \%) \\
13(1.9 \%) \\
413(61.7 \%) \\
51(7.6 \%)\end{array}$ & $P<0.001$ \\
\hline $\begin{array}{l}\text { Time from first IMCU/ICU } \\
\text { admission to outcome or } \\
\text { censoring (d) }\end{array}$ & & $17(9-31)$ & $16(8-33.5)$ & $18(10-33)$ & $16(9-30)$ & $18(9-30)$ & $P=0.63$ \\
\hline $\begin{array}{l}\text { Time from diagnosis to } \\
\text { first IMCU/ICU admission } \\
\text { (d) }\end{array}$ & & $3(0-7)$ & $2(0-5)$ & $0(0-3)$ & $4(0-8)$ & $4(0-8)$ & $P<0.001$ \\
\hline Age (years) & & $68(58-76)$ & $66(56-75)$ & $64(58-73)$ & $70(60-77)$ & $64(55-73)$ & $P<0.001$ \\
\hline Sex & $\begin{array}{l}\text { female } \\
\text { male }\end{array}$ & $\begin{array}{l}1216(32.5 \%) \\
2523(67.5 \%)\end{array}$ & $\begin{array}{l}248(30.3 \%) \\
571(69.7 \%)\end{array}$ & $\begin{array}{l}48(33.1 \%) \\
97(66.9 \%)\end{array}$ & $\begin{array}{l}661(31.4 \%) \\
1445(68.6 \%)\end{array}$ & $\begin{array}{l}259(38.7 \%) \\
410(61.3 \%)\end{array}$ & $P=0.59$ \\
\hline Obesity & $\begin{array}{l}\text { no } \\
\text { yes } \\
\text { unknown }\end{array}$ & $\begin{array}{l}1800(48.1 \%) \\
1198(32 \%) \\
741(19.8 \%)\end{array}$ & $\begin{array}{l}335(40.9 \%) \\
218(26.6 \%) \\
266(32.5 \%)\end{array}$ & $\begin{array}{l}59(40.7 \%) \\
52(35.9 \%) \\
34(23.4 \%)\end{array}$ & $\begin{array}{l}1096(52 \%) \\
680(32.3 \%) \\
330(15.7 \%)\end{array}$ & $\begin{array}{l}310(46.3 \%) \\
248(37.1 \%) \\
111(16.6 \%)\end{array}$ & $P<0.001$ \\
\hline Smoking & $\begin{array}{l}\text { no } \\
\text { yes } \\
\text { unknown }\end{array}$ & $\begin{array}{l}1982(53 \%) \\
472(12.6 \%) \\
1285(34.4 \%)\end{array}$ & $\begin{array}{l}474(57.9 \%) \\
84(10.3 \%) \\
261(31.9 \%)\end{array}$ & $\begin{array}{l}78(53.8 \%) \\
13(9 \%) \\
54(37.2 \%)\end{array}$ & $\begin{array}{l}1081(51.3 \%) \\
279(13.2 \%) \\
746(35.4 \%)\end{array}$ & $\begin{array}{l}349(52.2 \%) \\
96(14.3 \%) \\
224(33.5 \%)\end{array}$ & $P=0.0038$ \\
\hline Renal disease & $\begin{array}{l}\text { no } \\
\text { yes } \\
\text { unknown }\end{array}$ & $\begin{array}{l}3075(82.2 \%) \\
645(17.3 \%) \\
19(0.5 \%)\end{array}$ & $\begin{array}{l}695(84.9 \%) \\
121(14.8 \%) \\
3(0.4 \%)\end{array}$ & $\begin{array}{l}124(85.5 \%) \\
21(14.5 \%) \\
0(0 \%)\end{array}$ & $\begin{array}{l}1679(79.7 \%) \\
420(19.9 \%) \\
7(0.3 \%)\end{array}$ & $\begin{array}{l}577(86.2 \%) \\
83(12.4 \%) \\
9(1.3 \%)\end{array}$ & $P=0.0054$ \\
\hline Oncological pathology & $\begin{array}{l}\text { no } \\
\text { yes } \\
\text { unknown }\end{array}$ & $\begin{array}{l}3274(87.6 \%) \\
443(11.8 \%) \\
22(0.6 \%)\end{array}$ & $\begin{array}{l}740(90.4 \%) \\
76(9.3 \%) \\
3(0.4 \%)\end{array}$ & $\begin{array}{l}126(86.9 \%) \\
18(12.4 \%) \\
1(0.7 \%)\end{array}$ & $\begin{array}{l}1799(85.4 \%) \\
298(14.2 \%) \\
9(0.4 \%)\end{array}$ & $\begin{array}{l}609(91 \%) \\
51(7.6 \%) \\
9(1.3 \%)\end{array}$ & $P=0.0018$ \\
\hline
\end{tabular}




\begin{tabular}{|c|c|c|c|c|c|c|c|}
\hline & & $\begin{array}{l}\text { All } \\
N=3739\end{array}$ & $\begin{array}{l}\text { First wave } \\
\mathrm{N}=819\end{array}$ & $\begin{array}{l}\text { Intermediate phase } \\
\mathrm{N}=145\end{array}$ & $\begin{array}{l}\text { Second wave } \\
N=2106\end{array}$ & $\begin{array}{l}\text { Third wave } \\
N=669\end{array}$ & $\begin{array}{l}\text { P-value 1st } \\
\text { wave/2nd wave }\end{array}$ \\
\hline $\begin{array}{l}\text { Chronic respiratory } \\
\text { disease }\end{array}$ & $\begin{array}{l}\text { no } \\
\text { yes } \\
\text { unknown }\end{array}$ & $\begin{array}{l}2831(75.7 \%) \\
887(23.7 \%) \\
21(0.6 \%)\end{array}$ & $\begin{array}{l}619(75.6 \%) \\
198(24.2 \%) \\
2(0.2 \%)\end{array}$ & $\begin{array}{l}113(77.9 \%) \\
32(22.1 \%) \\
0(0 \%)\end{array}$ & $\begin{array}{l}1561(74.1 \%) \\
537(25.5 \%) \\
8(0.4 \%)\end{array}$ & $\begin{array}{l}538(80.4 \%) \\
120(17.9 \%) \\
11(1.6 \%)\end{array}$ & $P=0.64$ \\
\hline Cardiovascular disease & $\begin{array}{l}\text { no } \\
\text { yes } \\
\text { unknown }\end{array}$ & $\begin{array}{l}2414(64.6 \%) \\
1311(35.1 \%) \\
14(0.4 \%)\end{array}$ & $\begin{array}{l}572(69.8 \%) \\
247(30.2 \%) \\
0(0 \%)\end{array}$ & $\begin{array}{l}100(69 \%) \\
45(31 \%) \\
0(0 \%)\end{array}$ & $\begin{array}{l}1282(60.9 \%) \\
820(38.9 \%) \\
4(0.2 \%)\end{array}$ & $\begin{array}{l}460(68.8 \%) \\
199(29.7 \%) \\
10(1.5 \%)\end{array}$ & $P<0.001$ \\
\hline Dementia & $\begin{array}{l}\text { no } \\
\text { yes } \\
\text { unknown }\end{array}$ & $\begin{array}{l}3588(96 \%) \\
136(3.6 \%) \\
15(0.4 \%)\end{array}$ & $\begin{array}{l}794(96.9 \%) \\
24(2.9 \%) \\
1(0.1 \%)\end{array}$ & $\begin{array}{l}139(95.9 \%) \\
6(4.1 \%) \\
0(0 \%)\end{array}$ & $\begin{array}{l}2008(95.3 \%) \\
93(4.4 \%) \\
5(0.2 \%)\end{array}$ & $\begin{array}{l}647(96.7 \%) \\
13(1.9 \%) \\
9(1.3 \%)\end{array}$ & $P=0.15$ \\
\hline Invasive ventilation & $\begin{array}{l}\text { no } \\
\text { yes } \\
\text { unknown }\end{array}$ & $\begin{array}{l}1945(52 \%) \\
1762(47.1 \%) \\
32(0.9 \%)\end{array}$ & $\begin{array}{l}380(46.4 \%) \\
438(53.5 \%) \\
1(0.1 \%)\end{array}$ & $\begin{array}{l}69(47.6 \%) \\
76(52.4 \%) \\
0(0 \%)\end{array}$ & $\begin{array}{l}1140(54.1 \%) \\
952(45.2 \%) \\
14(0.7 \%)\end{array}$ & $\begin{array}{l}356(53.2 \%) \\
296(44.2 \%) \\
17(2.5 \%)\end{array}$ & $P<0.001$ \\
\hline Non-invasive ventilation & $\begin{array}{l}\text { no } \\
\text { yes } \\
\text { unknown }\end{array}$ & $\begin{array}{l}1452(38.8 \%) \\
2230(59.6 \%) \\
57(1.5 \%)\end{array}$ & $\begin{array}{l}369(45.1 \%) \\
445(54.3 \%) \\
5(0.6 \%)\end{array}$ & $\begin{array}{l}66(45.5 \%) \\
78(53.8 \%) \\
1(0.7 \%)\end{array}$ & $\begin{array}{l}808(38.4 \%) \\
1265(60.1 \%) \\
33(1.6 \%)\end{array}$ & $\begin{array}{l}209(31.2 \%) \\
442(66.1 \%) \\
18(2.7 \%)\end{array}$ & $P<0.001$ \\
\hline Immunosuppression & $\begin{array}{l}\text { no } \\
\text { yes } \\
\text { unknown }\end{array}$ & $\begin{array}{l}3357(89.8 \%) \\
345(9.2 \%) \\
37(1 \%)\end{array}$ & $\begin{array}{l}745(91 \%) \\
63(7.7 \%) \\
11(1.3 \%)\end{array}$ & $\begin{array}{l}135(93.1 \%) \\
10(6.9 \%) \\
0(0 \%)\end{array}$ & $\begin{array}{l}1880(89.3 \%) \\
214(10.2 \%) \\
12(0.6 \%)\end{array}$ & $\begin{array}{l}597(89.2 \%) \\
58(8.7 \%) \\
14(2.1 \%)\end{array}$ & $P=0.014$ \\
\hline Any comorbidity & $\begin{array}{l}\text { no } \\
\text { yes } \\
\text { unknown }\end{array}$ & $\begin{array}{l}556(14.9 \%) \\
3177(85 \%) \\
6(0.2 \%)\end{array}$ & $\begin{array}{l}148(18.1 \%) \\
671(81.9 \%) \\
0(0 \%)\end{array}$ & $\begin{array}{l}21(14.5 \%) \\
124(85.5 \%) \\
0(0 \%)\end{array}$ & $\begin{array}{l}254(12.1 \%) \\
1852(87.9 \%) \\
0(0 \%)\end{array}$ & $\begin{array}{l}133(19.9 \%) \\
530(79.2 \%) \\
6(0.9 \%)\end{array}$ & $P<0.001$ \\
\hline IMCU/ICU type & $\begin{array}{l}\text { both } \\
\text { ICU only } \\
\text { IMCU only } \\
\text { unknown }\end{array}$ & $\begin{array}{l}544(14.5 \%) \\
2164(57.9 \%) \\
1007(26.9 \%) \\
24(0.6 \%)\end{array}$ & $\begin{array}{l}181(22.1 \%) \\
350(42.7 \%) \\
285(34.8 \%) \\
3(0.4 \%)\end{array}$ & $\begin{array}{l}20(13.8 \%) \\
91(62.8 \%) \\
34(23.4 \%) \\
0(0 \%)\end{array}$ & $\begin{array}{l}277(13.2 \%) \\
1292(61.3 \%) \\
536(25.5 \%) \\
1(0 \%)\end{array}$ & $\begin{array}{l}66(9.9 \%) \\
431(64.4 \%) \\
152(22.7 \%) \\
20(3 \%)\end{array}$ & $P<0.001$ \\
\hline
\end{tabular}




\begin{tabular}{|c|c|c|c|c|c|c|c|}
\hline & & $\begin{array}{l}\text { All } \\
N=3739\end{array}$ & $\begin{array}{l}\text { First wave } \\
N=819\end{array}$ & $\begin{array}{l}\text { Intermediate phase } \\
\mathrm{N}=145\end{array}$ & $\begin{array}{l}\text { Second wave } \\
\mathrm{N}=2106\end{array}$ & $\begin{array}{l}\text { Third wave } \\
\mathrm{N}=669\end{array}$ & $\begin{array}{l}\mathrm{P} \text {-value 1st } \\
\text { wave/2nd wave }\end{array}$ \\
\hline CURB-65 score & $\begin{array}{l}0 \\
1 \\
2 \\
3 \\
4 \\
5\end{array}$ & $\begin{array}{l}757(20.2 \%) \\
1298(34.7 \%) \\
1101(29.4 \%) \\
457(12.2 \%) \\
106(2.8 \%) \\
20(0.5 \%)\end{array}$ & $\begin{array}{l}209(25.5 \%) \\
287(35 \%) \\
199(24.3 \%) \\
97(11.8 \%) \\
25(3.1 \%) \\
2(0.2 \%)\end{array}$ & $\begin{array}{l}34(23.4 \%) \\
53(36.6 \%) \\
39(26.9 \%) \\
17(11.7 \%) \\
1(0.7 \%) \\
1(0.7 \%)\end{array}$ & $\begin{array}{l}338(16 \%) \\
692(32.9 \%) \\
701(33.3 \%) \\
292(13.9 \%) \\
67(3.2 \%) \\
16(0.8 \%)\end{array}$ & $\begin{array}{l}176(26.3 \%) \\
266(39.8 \%) \\
162(24.2 \%) \\
51(7.6 \%) \\
13(1.9 \%) \\
1(0.1 \%)\end{array}$ & $P<0.001$ \\
\hline
\end{tabular}


Appendix 9: Cumulative incidence functions for discharge (upper left), transfer (upper right) and death from other cause than COVID-19 (bottom), for IMCU/ICU patients and for the different COVID-19 waves.
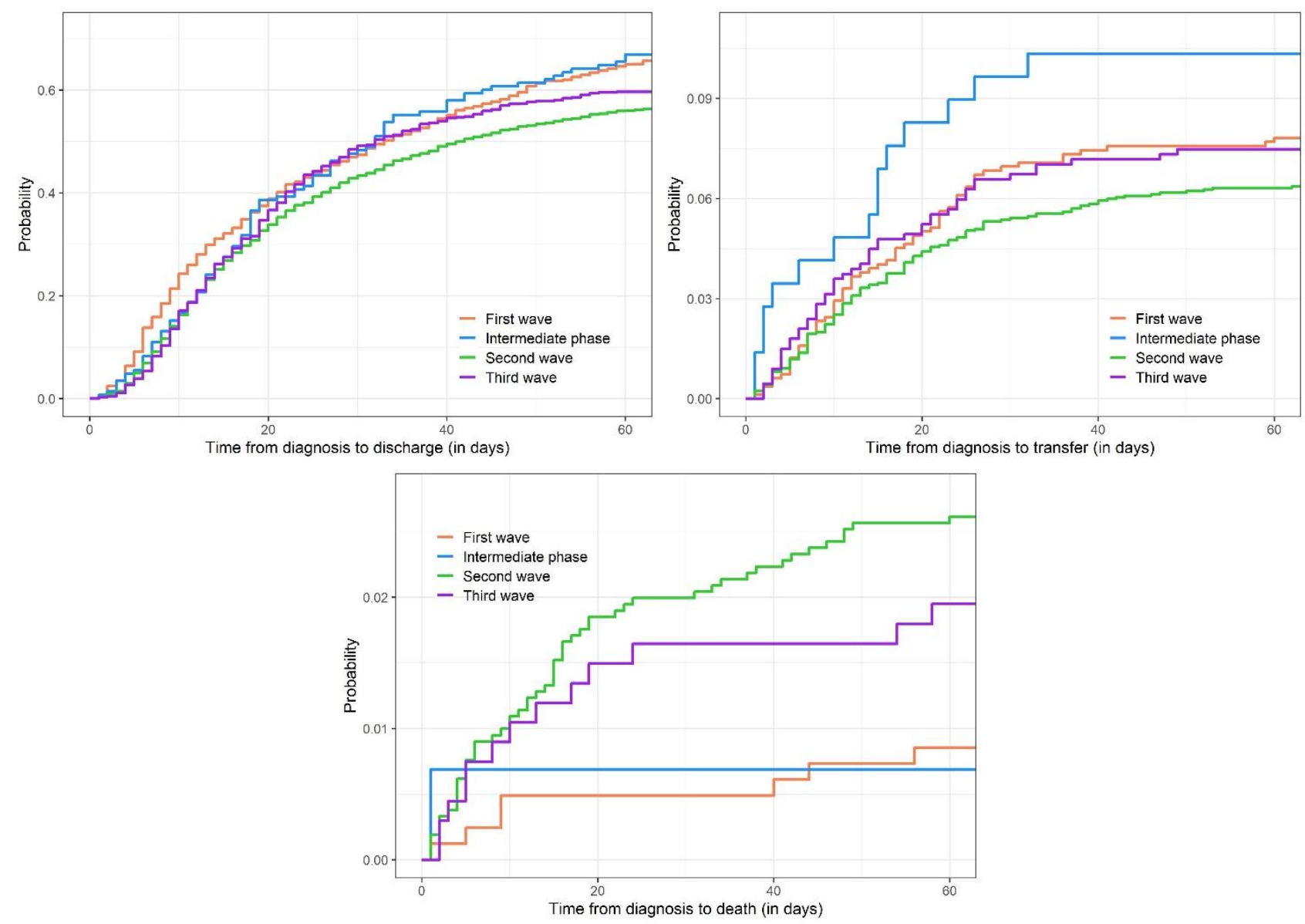
Appendix 10: Hazard ratios for in-IMCU/ICU mortality due to COVID-19, from the various Fine-Gray models calculated.

\begin{tabular}{|c|c|c|c|c|}
\hline & & $\begin{array}{l}\text { Multivariable, } \\
\text { imputed }\end{array}$ & $\begin{array}{l}\text { Multivariable, complete } \\
\text { cases }\end{array}$ & $\begin{array}{l}\text { Univariable,complete } \\
\text { cases }\end{array}$ \\
\hline \multirow[t]{5}{*}{ Age (years) } & & $P<0.001$ & $P<0.001$ & $P<0.001$ \\
\hline & 35 & $0.108(0.0611-0.192)$ & $0.0913(0.0391-0.213)$ & $0.0861(0.0483-0.154)$ \\
\hline & 50 & $0.351(0.277-0.446)$ & $0.328(0.229-0.469)$ & $0.316(0.248-0.402)$ \\
\hline & 65 & 1.0 (ref) & $1.0($ ref) & $1.0($ ref) \\
\hline & 80 & $2.01(1.77-2.27)$ & $1.93(1.62-2.29)$ & $2.14(1.92-2.38)$ \\
\hline \multirow[t]{3}{*}{ Sex } & & $P=0.12$ & $P=0.047$ & $P=0.26$ \\
\hline & Female & 1.0 (ref) & 1.0 (ref) & 1.0 (ref) \\
\hline & Male & $1.13(0.972-1.3)$ & $1.24(1-1.54)$ & $1.09(0.941-1.25)$ \\
\hline \multirow[t]{3}{*}{ Obesity } & & $P=0.72$ & $P=0.59$ & $P=0.0012$ \\
\hline & No & 1.0 (ref) & 1.0 (ref) & $1.0($ ref) \\
\hline & Yes & $0.972(0.833-1.13)$ & $1.06(0.869-1.28)$ & $0.777(0.667-0.905)$ \\
\hline \multirow[t]{3}{*}{ Smoking } & & $P=0.13$ & $P=0.33$ & $P=0.057$ \\
\hline & No & 1.0 (ref) & 1.0 (ref) & 1.0 (ref) \\
\hline & Yes & $1.17(0.952-1.44)$ & $1.12(0.891-1.42)$ & $1.21(0.994-1.48)$ \\
\hline \multirow[t]{3}{*}{ Renal disease } & & $P<0.001$ & $P<0.001$ & $P<0.001$ \\
\hline & No & 1.0 (ref) & 1.0 (ref) & 1.0 (ref) \\
\hline & Yes & $1.31(1.12-1.53)$ & $1.51(1.22-1.88)$ & $2.11(1.82-2.45)$ \\
\hline \multirow{3}{*}{$\begin{array}{l}\text { Oncological } \\
\text { pathology }\end{array}$} & & $P=0.017$ & $P=0.011$ & $P<0.001$ \\
\hline & No & 1.0 (ref) & 1.0 (ref) & 1.0 (ref) \\
\hline & Yes & $1.24(1.04-1.48)$ & $1.36(1.07-1.71)$ & $1.81(1.53-2.15)$ \\
\hline \multirow{3}{*}{$\begin{array}{l}\text { Chronic } \\
\text { respiratory } \\
\text { disease }\end{array}$} & & $P=0.29$ & $P=0.45$ & $P<0.001$ \\
\hline & No & 1.0 (ref) & 1.0 (ref) & 1.0 (ref) \\
\hline & Yes & $1.09(0.933-1.26)$ & $1.08(0.883-1.33)$ & $1.36(1.17-1.57)$ \\
\hline \multirow{3}{*}{$\begin{array}{l}\text { Cardiovascular } \\
\text { disease }\end{array}$} & & $P=0.049$ & $P=0.42$ & $P<0.001$ \\
\hline & No & 1.0 (ref) & 1.0 (ref) & 1.0 (ref) \\
\hline & Yes & $1.16(1-1.34)$ & $1.09(0.888-1.33)$ & $2.01(1.77-2.3)$ \\
\hline \multirow[t]{3}{*}{ Dementia } & & $P=0.51$ & $P=0.81$ & $P=0.002$ \\
\hline & No & 1.0 (ref) & 1.0 (ref) & 1.0 (ref) \\
\hline & Yes & $0.901(0.661-1.23)$ & $1.05(0.682-1.63)$ & $1.6(1.19-2.16)$ \\
\hline \multirow{3}{*}{$\begin{array}{l}\text { Immuno- } \\
\text { suppression }\end{array}$} & & $P<0.001$ & $P=0.013$ & $P<0.001$ \\
\hline & No & 1.0 (ref) & 1.0 (ref) & 1.0 (ref) \\
\hline & Yes & $1.6(1.32-1.94)$ & $1.41(1.07-1.85)$ & $1.8(1.49-2.17)$ \\
\hline \multirow[t]{5}{*}{ Time period } & & $P=0.029$ & $P=0.2$ & $P<0.001$ \\
\hline & First wave & 1.0 (ref) & 1.0 (ref) & 1.0 (ref) \\
\hline & Intermediate phase & $0.824(0.532-1.28)$ & $1.12(0.641-1.97)$ & $0.788(0.509-1.22)$ \\
\hline & Second wave & $1.25(1.05-1.49)$ & $1.33(1.02-1.74)$ & $1.49(1.25-1.78)$ \\
\hline & Third wave & $1.17(0.931-1.48)$ & $1.27(0.907-1.78)$ & $1.07(0.852-1.34)$ \\
\hline
\end{tabular}


Appendix 11: Hazard ratios for in-IMCU/ICU mortality due to COVID-19, from Cox models.

\begin{tabular}{|c|c|c|c|c|}
\hline & & $\begin{array}{l}\text { Multivariable, } \\
\text { imputed }\end{array}$ & $\begin{array}{l}\text { Multivariable, complete } \\
\text { cases }\end{array}$ & $\begin{array}{l}\text { Univariable,complete } \\
\text { cases }\end{array}$ \\
\hline \multirow[t]{5}{*}{ Age (years) } & & $P<0.001$ & $P<0.001$ & $P<0.001$ \\
\hline & 35 & $0.172(0.102-0.289)$ & $0.162(0.0761-0.344)$ & $0.144(0.0855-0.244)$ \\
\hline & 50 & $0.424(0.337-0.534)$ & $0.415(0.296-0.583)$ & $0.391(0.31-0.493)$ \\
\hline & 65 & 1.0 (ref) & 1.0 (ref) & 1.0 (ref) \\
\hline & 80 & $1.95(1.73-2.2)$ & $1.82(1.54-2.15)$ & $2.06(1.86-2.28)$ \\
\hline \multirow[t]{3}{*}{ Sex } & & $P=0.21$ & $P=0.092$ & $P=0.62$ \\
\hline & Female & 1.0 (ref) & 1.0 (ref) & 1.0 (ref) \\
\hline & Male & $1.1(0.948-1.27)$ & $1.2(0.971-1.49)$ & $1.04(0.899-1.19)$ \\
\hline \multirow[t]{3}{*}{ Obesity } & & $P=0.72$ & $P=0.55$ & $P=0.0028$ \\
\hline & No & 1.0 (ref) & 1.0 (ref) & 1.0 (ref) \\
\hline & Yes & $0.972(0.832-1.14)$ & $1.06(0.873-1.29)$ & $0.792(0.68-0.923)$ \\
\hline \multirow[t]{3}{*}{ Smoking } & & $P=0.069$ & $P=0.19$ & $P=0.04$ \\
\hline & No & 1.0 (ref) & 1.0 (ref) & 1.0 (ref) \\
\hline & Yes & $1.2(0.986-1.47)$ & $1.17(0.926-1.47)$ & $1.23(1.01-1.51)$ \\
\hline \multirow[t]{3}{*}{ Renal disease } & & $P<0.001$ & $P<0.001$ & $P<0.001$ \\
\hline & No & 1.0 (ref) & 1.0 (ref) & 1.0 (ref) \\
\hline & Yes & $1.31(1.12-1.53)$ & $1.52(1.23-1.88)$ & $1.9(1.64-2.2)$ \\
\hline \multirow{3}{*}{$\begin{array}{l}\text { Oncological } \\
\text { pathology }\end{array}$} & & $P=0.021$ & $P=0.0067$ & $P<0.001$ \\
\hline & No & 1.0 (ref) & 1.0 (ref) & 1.0 (ref) \\
\hline & Yes & $1.23(1.03-1.48)$ & $1.39(1.09-1.75)$ & $1.71(1.44-2.03)$ \\
\hline \multirow{3}{*}{$\begin{array}{l}\text { Chronic respiratory } \\
\text { disease }\end{array}$} & & $P=0.7$ & $P=0.75$ & $P=0.0029$ \\
\hline & No & 1.0 (ref) & 1.0 (ref) & 1.0 (ref) \\
\hline & Yes & $1.03(0.886-1.2)$ & $1.03(0.843-1.27)$ & $1.25(1.08-1.44)$ \\
\hline \multirow{3}{*}{$\begin{array}{l}\text { Cardiovascular } \\
\text { disease }\end{array}$} & & $P=0.14$ & $P=0.46$ & $P<0.001$ \\
\hline & No & 1.0 (ref) & 1.0 (ref) & 1.0 (ref) \\
\hline & Yes & $1.12(0.966-1.29)$ & $1.08(0.881-1.32)$ & $1.8(1.58-2.05)$ \\
\hline \multirow[t]{3}{*}{ Dementia } & & $P=0.75$ & $P=0.8$ & $P=0.0088$ \\
\hline & No & 1.0 (ref) & 1.0 (ref) & 1.0 (ref) \\
\hline & Yes & $0.95(0.697-1.29)$ & $1.06(0.684-1.64)$ & $1.49(1.11-2.01)$ \\
\hline \multirow{3}{*}{$\begin{array}{l}\text { Immuno- } \\
\text { suppression }\end{array}$} & & $P<0.001$ & $P=0.03$ & $P<0.001$ \\
\hline & No & 1.0 (ref) & 1.0 (ref) & 1.0 (ref) \\
\hline & Yes & $1.52(1.25-1.85)$ & $1.35(1.03-1.78)$ & $1.59(1.32-1.92)$ \\
\hline \multirow[t]{5}{*}{ Time period } & & $P=0.012$ & $P=0.026$ & $P<0.001$ \\
\hline & First wave & 1.0 (ref) & 1.0 (ref) & 1.0 (ref) \\
\hline & Intermediate phase & $0.801(0.517-1.24)$ & $1.11(0.634-1.95)$ & $0.765(0.494-1.18)$ \\
\hline & Second wave & $1.28(1.07-1.53)$ & $1.49(1.14-1.94)$ & $1.43(1.2-1.71)$ \\
\hline & Third wave & $1.18(0.935-1.49)$ & $1.42(1.02-2)$ & $1.03(0.823-1.3)$ \\
\hline
\end{tabular}


Appendix 12: Same as Appendix 10, for in-IMCU/ICU all-cause mortality within CH-SUR.

\begin{tabular}{|c|c|c|c|c|}
\hline & & Multivariable, imputed & $\begin{array}{l}\text { Multivariable, complete } \\
\text { cases }\end{array}$ & $\begin{array}{l}\text { Univariable,complete } \\
\text { cases }\end{array}$ \\
\hline \multirow[t]{5}{*}{ Age (years) } & & $P<0.001$ & $P<0.001$ & $P<0.001$ \\
\hline & 35 & $0.135(0.0803-0.228)$ & $0.113(0.0518-0.248)$ & $0.108(0.0638-0.183)$ \\
\hline & 50 & $0.386(0.311-0.479)$ & $0.358(0.258-0.497)$ & $0.347(0.28-0.431)$ \\
\hline & 65 & 1.0 (ref) & 1.0 (ref) & 1.0 (ref) \\
\hline & 80 & $2.04(1.81-2.3)$ & $2(1.7-2.36)$ & $2.2(1.98-2.44)$ \\
\hline \multirow[t]{3}{*}{ Sex } & & $P=0.032$ & $P=0.019$ & $P=0.15$ \\
\hline & Female & 1.0 (ref) & 1.0 (ref) & 1.0 (ref) \\
\hline & Male & $1.17(1.01-1.35)$ & $1.28(1.04-1.56)$ & $1.11(0.965-1.27)$ \\
\hline \multirow[t]{3}{*}{ Obesity } & & $P=0.45$ & $P=0.92$ & $P<0.001$ \\
\hline & No & 1.0 (ref) & 1.0 (ref) & 1.0 (ref) \\
\hline & Yes & $0.943(0.811-1.1)$ & $0.99(0.823-1.19)$ & $0.751(0.648-0.869)$ \\
\hline \multirow[t]{3}{*}{ Smoking } & & $P=0.1$ & $P=0.2$ & $P=0.029$ \\
\hline & No & 1.0 (ref) & 1.0 (ref) & 1.0 (ref) \\
\hline & Yes & $1.18(0.967-1.44)$ & $1.15(0.927-1.44)$ & $1.24(1.02-1.49)$ \\
\hline \multirow[t]{3}{*}{ Renal disease } & & $P<0.001$ & $P<0.001$ & $P<0.001$ \\
\hline & No & 1.0 (ref) & 1.0 (ref) & 1.0 (ref) \\
\hline & Yes & $1.32(1.14-1.54)$ & $1.58(1.29-1.93)$ & $2.14(1.86-2.46)$ \\
\hline \multirow{3}{*}{$\begin{array}{l}\text { Oncological } \\
\text { pathology }\end{array}$} & & $P=0.0038$ & $P=0.0039$ & $P<0.001$ \\
\hline & No & 1.0 (ref) & 1.0 (ref) & 1.0 (ref) \\
\hline & Yes & $1.28(1.08-1.52)$ & $1.39(1.11-1.73)$ & $1.89(1.61-2.23)$ \\
\hline \multirow{3}{*}{$\begin{array}{l}\text { Chronic } \\
\text { respiratory } \\
\text { disease }\end{array}$} & & $P=0.23$ & $P=0.38$ & $P<0.001$ \\
\hline & No & 1.0 (ref) & 1.0 (ref) & 1.0 (ref) \\
\hline & Yes & $1.09(0.946-1.26)$ & $1.09(0.898-1.32)$ & $1.36(1.19-1.57)$ \\
\hline \multirow{3}{*}{$\begin{array}{l}\text { Cardiovascular } \\
\text { disease }\end{array}$} & & $P=0.061$ & $P=0.44$ & $P<0.001$ \\
\hline & No & 1.0 (ref) & 1.0 (ref) & 1.0 (ref) \\
\hline & Yes & $1.14(0.994-1.31)$ & $1.08(0.889-1.31)$ & $2.03(1.79-2.3)$ \\
\hline \multirow[t]{3}{*}{ Dementia } & & $P=0.85$ & $P=0.43$ & $P<0.001$ \\
\hline & No & 1.0 (ref) & 1.0 (ref) & 1.0 (ref) \\
\hline & Yes & $1.03(0.775-1.36)$ & $1.17(0.79-1.75)$ & $1.81(1.38-2.38)$ \\
\hline \multirow{3}{*}{$\begin{array}{l}\text { Immuno- } \\
\text { suppression }\end{array}$} & & $P<0.001$ & $P=0.0016$ & $P<0.001$ \\
\hline & No & 1.0 (ref) & 1.0 (ref) & 1.0 (ref) \\
\hline & Yes & $1.64(1.37-1.98)$ & $1.51(1.17-1.94)$ & $1.83(1.53-2.19)$ \\
\hline \multirow[t]{5}{*}{ Time period } & & $P=0.0017$ & $P=0.066$ & $P<0.001$ \\
\hline & First wave & 1.0 (ref) & 1.0 (ref) & 1.0 (ref) \\
\hline & Intermediate phase & $0.82(0.534-1.26)$ & $1.01(0.581-1.77)$ & $0.786(0.513-1.2)$ \\
\hline & Second wave & $1.34(1.13-1.59)$ & $1.38(1.07-1.78)$ & $1.58(1.33-1.88)$ \\
\hline & Third wave & $1.25(1-1.57)$ & $1.27(0.923-1.75)$ & $1.12(0.901-1.4)$ \\
\hline
\end{tabular}


Appendix 13: Same as Appendix 11 for in-IMCU/ICU all-cause mortality within CH-SUR

\begin{tabular}{|c|c|c|c|c|}
\hline & & $\begin{array}{l}\text { Multivariable, } \\
\text { imputed }\end{array}$ & $\begin{array}{l}\text { Multivariable, complete } \\
\text { cases }\end{array}$ & $\begin{array}{l}\text { Univariable,complete } \\
\text { cases }\end{array}$ \\
\hline \multirow[t]{5}{*}{ Age (years) } & & $P<0.001$ & $P<0.001$ & $P<0.001$ \\
\hline & 35 & $0.172(0.102-0.289)$ & $0.191(0.0957-0.383)$ & $0.176(0.109-0.283)$ \\
\hline & 50 & $0.424(0.337-0.534)$ & $0.447(0.328-0.611)$ & $0.426(0.345-0.526)$ \\
\hline & 65 & 1.0 (ref) & 1.0 (ref) & 1.0 (ref) \\
\hline & 80 & $1.95(1.73-2.2)$ & $1.84(1.57-2.16)$ & $2.06(1.87-2.28)$ \\
\hline \multirow[t]{3}{*}{ Sex } & & $P=0.21$ & $P=0.056$ & $P=0.48$ \\
\hline & Female & 1.0 (ref) & 1.0 (ref) & 1.0 (ref) \\
\hline & Male & $1.1(0.948-1.27)$ & $1.22(0.995-1.49)$ & $1.05(0.916-1.2)$ \\
\hline \multirow[t]{3}{*}{ Obesity } & & $P=0.72$ & $P=0.85$ & $P<0.001$ \\
\hline & No & 1.0 (ref) & 1.0 (ref) & 1.0 (ref) \\
\hline & Yes & $0.972(0.832-1.14)$ & $1.02(0.844-1.23)$ & $0.773(0.667-0.895)$ \\
\hline \multirow[t]{3}{*}{ Smoking } & & $P=0.069$ & $P=0.097$ & $P=0.019$ \\
\hline & No & 1.0 (ref) & 1.0 (ref) & 1.0 (ref) \\
\hline & Yes & $1.2(0.986-1.47)$ & $1.2(0.967-1.5)$ & $1.25(1.04-1.52)$ \\
\hline \multirow[t]{3}{*}{ Renal disease } & & $P<0.001$ & $P<0.001$ & $P<0.001$ \\
\hline & No & 1.0 (ref) & 1.0 (ref) & 1.0 (ref) \\
\hline & Yes & $1.31(1.12-1.53)$ & $1.57(1.28-1.92)$ & $1.9(1.65-2.19)$ \\
\hline \multirow{3}{*}{$\begin{array}{l}\text { Oncological } \\
\text { pathology }\end{array}$} & & $P=0.021$ & $P=0.0025$ & $P<0.001$ \\
\hline & No & 1.0 (ref) & 1.0 (ref) & 1.0 (ref) \\
\hline & Yes & $1.23(1.03-1.48)$ & $1.41(1.13-1.76)$ & $1.77(1.5-2.08)$ \\
\hline \multirow{3}{*}{$\begin{array}{l}\text { Chronic } \\
\text { respiratory } \\
\text { disease }\end{array}$} & & $P=0.7$ & $P=0.66$ & $P=0.0017$ \\
\hline & No & 1.0 (ref) & 1.0 (ref) & 1.0 (ref) \\
\hline & Yes & $1.03(0.886-1.2)$ & $1.04(0.861-1.27)$ & $1.25(1.09-1.44)$ \\
\hline \multirow{3}{*}{$\begin{array}{l}\text { Cardiovascular } \\
\text { disease }\end{array}$} & & $P=0.14$ & $P=0.45$ & $P<0.001$ \\
\hline & No & 1.0 (ref) & 1.0 (ref) & 1.0 (ref) \\
\hline & Yes & $1.12(0.966-1.29)$ & $1.08(0.888-1.31)$ & $1.79(1.58-2.03)$ \\
\hline \multirow[t]{3}{*}{ Dementia } & & $P=0.75$ & $P=0.52$ & $P<0.001$ \\
\hline & No & 1.0 (ref) & 1.0 (ref) & 1.0 (ref) \\
\hline & Yes & $0.95(0.697-1.29)$ & $1.14(0.764-1.7)$ & $1.64(1.25-2.16)$ \\
\hline \multirow{3}{*}{$\begin{array}{l}\text { Immuno- } \\
\text { suppression }\end{array}$} & & $P<0.001$ & $P=0.0095$ & $P<0.001$ \\
\hline & No & 1.0 (ref) & 1.0 (ref) & 1.0 (ref) \\
\hline & Yes & $1.52(1.25-1.85)$ & $1.41(1.09-1.82)$ & $1.61(1.35-1.92)$ \\
\hline \multirow[t]{5}{*}{ Time period } & & $P=0.012$ & $P=0.0079$ & $P<0.001$ \\
\hline & First wave & 1.0 (ref) & 1.0 (ref) & 1.0 (ref) \\
\hline & Intermediate phase & $0.801(0.517-1.24)$ & $1.02(0.582-1.77)$ & $0.76(0.495-1.17)$ \\
\hline & Second wave & $1.28(1.07-1.53)$ & $1.52(1.18-1.95)$ & $1.5(1.27-1.78)$ \\
\hline & Third wave & $1.18(0.935-1.49)$ & $1.41(1.02-1.95)$ & $1.08(0.864-1.34)$ \\
\hline
\end{tabular}




\begin{tabular}{|c|c|c|c|c|c|c|c|}
\hline & & $\begin{array}{l}\text { All } \\
N=2716\end{array}$ & First wave $\mathrm{N}=533$ & $\begin{array}{l}\text { Intermediate phase } \\
\mathrm{N}=111\end{array}$ & $\begin{array}{l}\text { Second wave } \\
N=1570\end{array}$ & Third wave $\mathrm{N}=502$ & P-value 1st wave/2nd wave \\
\hline Outcome & $\begin{array}{l}\text { Censored } \\
\text { Deceased - COVID-19 } \\
\text { Deceased - other } \\
\text { Discharged } \\
\text { Transferred }\end{array}$ & $\begin{array}{l}79(2.9 \%) \\
717(26.4 \%) \\
60(2.2 \%) \\
1623(59.8 \%) \\
237(8.7 \%)\end{array}$ & $\begin{array}{l}0(0 \%) \\
123(23.1 \%) \\
7(1.3 \%) \\
350(65.7 \%) \\
53(9.9 \%)\end{array}$ & $\begin{array}{l}2(1.8 \%) \\
18(16.2 \%) \\
1(0.9 \%) \\
74(66.7 \%) \\
16(14.4 \%)\end{array}$ & $\begin{array}{l}42(2.7 \%) \\
464(29.6 \%) \\
42(2.7 \%) \\
903(57.5 \%) \\
119(7.6 \%)\end{array}$ & $\begin{array}{l}35(7 \%) \\
112(22.3 \%) \\
10(2 \%) \\
296(59 \%) \\
49(9.8 \%)\end{array}$ & $P<0.001$ \\
\hline $\begin{array}{l}\text { Time from first } \\
\text { IMCU/ICU } \\
\text { admission to } \\
\text { outcome or } \\
\text { censoring (d) }\end{array}$ & & $19(10.8-34)$ & $23(12-41)$ & $18(10-32.5)$ & $18(10-33)$ & $19(11-29.8)$ & $P<0.001$ \\
\hline $\begin{array}{l}\text { Time from diagnosis } \\
\text { to first IMCU/ICU } \\
\text { admission (d) }\end{array}$ & & $3(0-8)$ & $3(0-6)$ & $0(0-3)$ & $4(0-8)$ & $4(0-8)$ & $P<0.001$ \\
\hline Age (years) & & $67(58-74)$ & $66(57-74)$ & $63(57-70)$ & $68(59-75)$ & $64(56-71)$ & $P=0.0023$ \\
\hline Sex & $\begin{array}{l}\text { female } \\
\text { male }\end{array}$ & $\begin{array}{l}820(30.2 \%) \\
1896(69.8 \%)\end{array}$ & $\begin{array}{l}136(25.5 \%) \\
397(74.5 \%)\end{array}$ & $\begin{array}{l}35(31.5 \%) \\
76(68.5 \%)\end{array}$ & $\begin{array}{l}470(29.9 \%) \\
1100(70.1 \%)\end{array}$ & $\begin{array}{l}179(35.7 \%) \\
323(64.3 \%)\end{array}$ & $P=0.059$ \\
\hline Obesity & $\begin{array}{l}\text { no } \\
\text { yes } \\
\text { unknown }\end{array}$ & $\begin{array}{l}1274(46.9 \%) \\
946(34.8 \%) \\
496(18.3 \%)\end{array}$ & $\begin{array}{l}241(45.2 \%) \\
158(29.6 \%) \\
134(25.1 \%)\end{array}$ & $\begin{array}{l}42(37.8 \%) \\
45(40.5 \%) \\
24(21.6 \%)\end{array}$ & $\begin{array}{l}774(49.3 \%) \\
541(34.5 \%) \\
255(16.2 \%)\end{array}$ & $\begin{array}{l}217(43.2 \%) \\
202(40.2 \%) \\
83(16.5 \%)\end{array}$ & $P<0.001$ \\
\hline Smoking & $\begin{array}{l}\text { no } \\
\text { yes } \\
\text { unknown }\end{array}$ & $\begin{array}{l}1355(49.9 \%) \\
347(12.8 \%) \\
1014(37.3 \%)\end{array}$ & $\begin{array}{l}295(55.3 \%) \\
50(9.4 \%) \\
188(35.3 \%)\end{array}$ & $\begin{array}{l}59(53.2 \%) \\
10(9 \%) \\
42(37.8 \%)\end{array}$ & $\begin{array}{l}760(48.4 \%) \\
211(13.4 \%) \\
599(38.2 \%)\end{array}$ & $\begin{array}{l}241(48 \%) \\
76(15.1 \%) \\
185(36.9 \%)\end{array}$ & $P=0.0068$ \\
\hline Renal disease & $\begin{array}{l}\text { no } \\
\text { yes } \\
\text { unknown }\end{array}$ & $\begin{array}{l}2240(82.5 \%) \\
461(17 \%) \\
15(0.6 \%)\end{array}$ & $\begin{array}{l}460(86.3 \%) \\
71(13.3 \%) \\
2(0.4 \%)\end{array}$ & $\begin{array}{l}94(84.7 \%) \\
17(15.3 \%) \\
0(0 \%)\end{array}$ & $\begin{array}{l}1252(79.7 \%) \\
311(19.8 \%) \\
7(0.4 \%)\end{array}$ & $\begin{array}{l}434(86.5 \%) \\
62(12.4 \%) \\
6(1.2 \%)\end{array}$ & $P=0.0034$ \\
\hline $\begin{array}{l}\text { Oncological } \\
\text { pathology }\end{array}$ & $\begin{array}{l}\text { no } \\
\text { yes } \\
\text { unknown }\end{array}$ & $\begin{array}{l}2405(88.5 \%) \\
298(11 \%) \\
13(0.5 \%)\end{array}$ & $\begin{array}{l}492(92.3 \%) \\
41(7.7 \%) \\
0(0 \%)\end{array}$ & $\begin{array}{l}95(85.6 \%) \\
16(14.4 \%) \\
0(0 \%)\end{array}$ & $\begin{array}{l}1359(86.6 \%) \\
204(13 \%) \\
7(0.4 \%)\end{array}$ & $\begin{array}{l}459(91.4 \%) \\
37(7.4 \%) \\
6(1.2 \%)\end{array}$ & $P=0.0012$ \\
\hline
\end{tabular}




\begin{tabular}{|c|c|c|c|c|c|c|c|}
\hline & & $\begin{array}{l}\text { All } \\
\mathrm{N}=\mathbf{2 7 1 6}\end{array}$ & First wave $\mathrm{N}=533$ & $\begin{array}{l}\text { Intermediate phase } \\
\mathrm{N}=111\end{array}$ & $\begin{array}{l}\text { Second wave } \\
N=1570\end{array}$ & Third wave $\mathrm{N}=502$ & P-value 1st wave/2nd wave \\
\hline $\begin{array}{l}\text { Chronic respiratory } \\
\text { disease }\end{array}$ & $\begin{array}{l}\text { no } \\
\text { yes } \\
\text { unknown }\end{array}$ & $\begin{array}{l}2080(76.6 \%) \\
621(22.9 \%) \\
15(0.6 \%)\end{array}$ & $\begin{array}{l}406(76.2 \%) \\
126(23.6 \%) \\
1(0.2 \%)\end{array}$ & $\begin{array}{l}91(82 \%) \\
20(18 \%) \\
0(0 \%)\end{array}$ & $\begin{array}{l}1172(74.6 \%) \\
391(24.9 \%) \\
7(0.4 \%)\end{array}$ & $\begin{array}{l}411(81.9 \%) \\
84(16.7 \%) \\
7(1.4 \%)\end{array}$ & $P=0.58$ \\
\hline $\begin{array}{l}\text { Cardiovascular } \\
\text { disease }\end{array}$ & $\begin{array}{l}\text { no } \\
\text { yes } \\
\text { unknown }\end{array}$ & $\begin{array}{l}1792(66 \%) \\
913(33.6 \%) \\
11(0.4 \%) \\
\end{array}$ & $\begin{array}{l}369(69.2 \%) \\
164(30.8 \%) \\
0(0 \%)\end{array}$ & $\begin{array}{l}79(71.2 \%) \\
32(28.8 \%) \\
0(0 \%) \\
\end{array}$ & $\begin{array}{l}986(62.8 \%) \\
580(36.9 \%) \\
4(0.3 \%)\end{array}$ & $\begin{array}{l}358(71.3 \%) \\
137(27.3 \%) \\
7(1.4 \%) \\
\end{array}$ & $P=0.017$ \\
\hline Dementia & $\begin{array}{l}\text { no } \\
\text { yes } \\
\text { unknown }\end{array}$ & $\begin{array}{l}2630(96.8 \%) \\
77(2.8 \%) \\
9(0.3 \%)\end{array}$ & $\begin{array}{l}522(97.9 \%) \\
11(2.1 \%) \\
0(0 \%)\end{array}$ & $\begin{array}{l}111(100 \%) \\
0(0 \%) \\
0(0 \%)\end{array}$ & $\begin{array}{l}1507(96 \%) \\
60(3.8 \%) \\
3(0.2 \%)\end{array}$ & $\begin{array}{l}490(97.6 \%) \\
6(1.2 \%) \\
6(1.2 \%)\end{array}$ & $P=0.09$ \\
\hline Immunosuppression & $\begin{array}{l}\text { no } \\
\text { yes } \\
\text { unknown }\end{array}$ & $\begin{array}{l}2427(89.4 \%) \\
262(9.6 \%) \\
27(1 \%)\end{array}$ & $\begin{array}{l}481(90.2 \%) \\
42(7.9 \%) \\
10(1.9 \%)\end{array}$ & $\begin{array}{l}105(94.6 \%) \\
6(5.4 \%) \\
0(0 \%)\end{array}$ & $\begin{array}{l}1397(89 \%) \\
166(10.6 \%) \\
7(0.4 \%)\end{array}$ & $\begin{array}{l}444(88.4 \%) \\
48(9.6 \%) \\
10(2 \%)\end{array}$ & $P=0.0015$ \\
\hline Any comorbidity & $\begin{array}{l}\text { no } \\
\text { yes } \\
\text { unknown }\end{array}$ & $\begin{array}{l}410(15.1 \%) \\
2303(84.8 \%) \\
3(0.1 \%)\end{array}$ & $\begin{array}{l}96(18 \%) \\
437(82 \%) \\
0(0 \%)\end{array}$ & $\begin{array}{l}16(14.4 \%) \\
95(85.6 \%) \\
0(0 \%)\end{array}$ & $\begin{array}{l}195(12.4 \%) \\
1375(87.6 \%) \\
0(0 \%)\end{array}$ & $\begin{array}{l}103(20.5 \%) \\
396(78.9 \%) \\
3(0.6 \%)\end{array}$ & $P=0.0016$ \\
\hline CURB-65 score & $\begin{array}{l}0 \\
1 \\
2 \\
3 \\
4 \\
5\end{array}$ & $\begin{array}{l}516(19 \%) \\
951(35 \%) \\
796(29.3 \%) \\
345(12.7 \%) \\
90(3.3 \%) \\
18(0.7 \%)\end{array}$ & $\begin{array}{l}112(21 \%) \\
195(36.6 \%) \\
141(26.5 \%) \\
63(11.8 \%) \\
20(3.8 \%) \\
2(0.4 \%)\end{array}$ & $\begin{array}{l}26(23.4 \%) \\
41(36.9 \%) \\
29(26.1 \%) \\
13(11.7 \%) \\
1(0.9 \%) \\
1(0.9 \%)\end{array}$ & $\begin{array}{l}249(15.9 \%) \\
510(32.5 \%) \\
506(32.2 \%) \\
232(14.8 \%) \\
59(3.8 \%) \\
14(0.9 \%)\end{array}$ & $\begin{array}{l}129(25.7 \%) \\
205(40.8 \%) \\
120(23.9 \%) \\
37(7.4 \%) \\
10(2 \%) \\
1(0.2 \%)\end{array}$ & $P=0.0059$ \\
\hline
\end{tabular}


Appendix 15: Cumulative incidence functions for death due to COVID-19 (upper left), discharge (upper right), transfer (bottom left) and death from other cause than COVID-19 (bottom right), for ICU patients and for the different COVID-

19 waves.
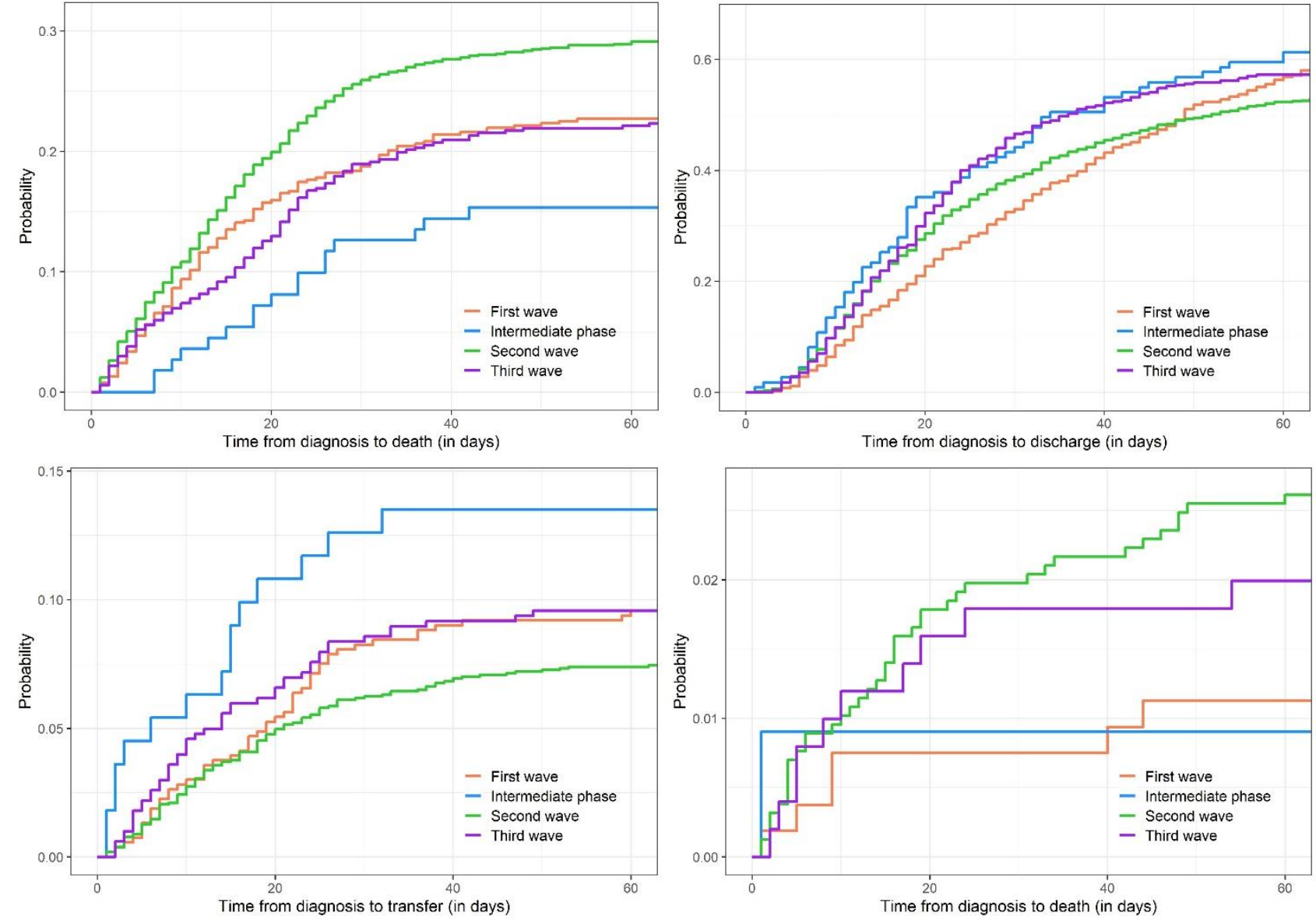
Appendix 16: Hazard ratios for in-ICU COVID-19 mortality from Fine-Gray models.

\begin{tabular}{|c|c|c|c|c|}
\hline & & $\begin{array}{l}\text { Multivariable, } \\
\text { imputed }\end{array}$ & $\begin{array}{l}\text { Multivariable, complete } \\
\text { cases }\end{array}$ & $\begin{array}{l}\text { Univariable,complete } \\
\text { cases }\end{array}$ \\
\hline \multirow[t]{5}{*}{ Age (years) } & & $P<0.001$ & $P<0.001$ & $P<0.001$ \\
\hline & 35 & $0.124(0.0665-0.232)$ & $0.0911(0.0338-0.245)$ & $0.103(0.0547-0.193)$ \\
\hline & 50 & $0.372(0.287-0.481)$ & $0.327(0.217-0.491)$ & $0.339(0.262-0.44)$ \\
\hline & 65 & 1.0 (ref) & 1.0 (ref) & $1.0($ ref) \\
\hline & 80 & $2.03(1.73-2.38)$ & $2.02(1.58-2.58)$ & $2.19(1.89-2.53)$ \\
\hline \multirow[t]{3}{*}{ Sex } & & $P=0.74$ & $P=0.16$ & $P=0.53$ \\
\hline & Female & 1.0 (ref) & 1.0 (ref) & 1.0 (ref) \\
\hline & Male & $1.03(0.871-1.21)$ & $1.19(0.934-1.51)$ & $1.05(0.896-1.24)$ \\
\hline \multirow[t]{3}{*}{ Obesity } & & $P=0.62$ & $P=0.99$ & $P=0.011$ \\
\hline & No & 1.0 (ref) & 1.0 (ref) & 1.0 (ref) \\
\hline & Yes & $0.955(0.796-1.15)$ & $1(0.807-1.24)$ & $0.804(0.68-0.952)$ \\
\hline \multirow[t]{3}{*}{ Smoking } & & $P=0.56$ & $P=0.69$ & $P=0.075$ \\
\hline & No & 1.0 (ref) & 1.0 (ref) & 1.0 (ref) \\
\hline & Yes & $1.07(0.857-1.33)$ & $1.05(0.815-1.36)$ & $1.22(0.98-1.52)$ \\
\hline \multirow[t]{3}{*}{ Renal disease } & & $P=0.028$ & $P=0.012$ & $P<0.001$ \\
\hline & No & 1.0 (ref) & 1.0 (ref) & 1.0 (ref) \\
\hline & Yes & $1.22(1.02-1.47)$ & $1.38(1.07-1.77)$ & $1.94(1.64-2.29)$ \\
\hline \multirow{3}{*}{$\begin{array}{l}\text { Oncological } \\
\text { pathology }\end{array}$} & & $P=0.0068$ & $P=0.0063$ & $P<0.001$ \\
\hline & No & 1.0 (ref) & 1.0 (ref) & 1.0 (ref) \\
\hline & Yes & $1.32(1.08-1.62)$ & $1.46(1.11-1.91)$ & $1.9(1.56-2.3)$ \\
\hline \multirow{3}{*}{$\begin{array}{l}\text { Chronic } \\
\text { respiratory } \\
\text { disease }\end{array}$} & & $P=0.088$ & $P=0.069$ & $P<0.001$ \\
\hline & No & 1.0 (ref) & 1.0 (ref) & 1.0 (ref) \\
\hline & Yes & $1.16(0.978-1.37)$ & $1.23(0.984-1.55)$ & $1.43(1.22-1.68)$ \\
\hline \multirow{3}{*}{$\begin{array}{l}\text { Cardiovascular } \\
\text { disease }\end{array}$} & & $P=0.061$ & $P=0.25$ & $P<0.001$ \\
\hline & No & 1.0 (ref) & 1.0 (ref) & 1.0 (ref) \\
\hline & Yes & $1.17(0.993-1.37)$ & $1.14(0.909-1.44)$ & $1.88(1.62-2.18)$ \\
\hline \multirow[t]{3}{*}{ Dementia } & & $P=0.027$ & $P=0.094$ & $P=0.42$ \\
\hline & No & 1.0 (ref) & 1.0 (ref) & 1.0 (ref) \\
\hline & Yes & $0.611(0.395-0.947)$ & $0.541(0.264-1.11)$ & $1.19(0.78-1.81)$ \\
\hline \multirow{3}{*}{$\begin{array}{l}\text { Immuno- } \\
\text { suppression }\end{array}$} & & $P<0.001$ & $P=0.046$ & $P<0.001$ \\
\hline & No & 1.0 (ref) & 1.0 (ref) & 1.0 (ref) \\
\hline & Yes & $1.54(1.24-1.91)$ & $1.37(1.01-1.86)$ & $1.75(1.42-2.16)$ \\
\hline \multirow[t]{5}{*}{ Time period } & & $P=0.13$ & $P=0.27$ & $P<0.001$ \\
\hline & First wave & 1.0 (ref) & 1.0 (ref) & 1.0 (ref) \\
\hline & Intermediate phase & $0.737(0.448-1.21)$ & $0.924(0.48-1.78)$ & $0.661(0.404-1.08)$ \\
\hline & Second wave & $1.17(0.956-1.43)$ & $1.3(0.962-1.77)$ & $1.33(1.09-1.63)$ \\
\hline & Third wave & $1.07(0.83-1.39)$ & $1.27(0.865-1.85)$ & $0.953(0.738-1.23)$ \\
\hline
\end{tabular}


Appendix 17: COVID-19 mortality in some European countries, expressed in deaths per million, from Our World in Data (OWID) [25]. Red colour indicates numbers higher than in Switzerland for the period of interest, green colour indicates numbers lower than Switzerland for the period of interest.

\begin{tabular}{|c|c|c|}
\hline Country & $\begin{array}{c}\text { First wave (February to } \\
\text { April 2020) }\end{array}$ & $\begin{array}{c}\text { Second wave (October } \\
\text { 2020 to February 2021) }\end{array}$ \\
\hline Switzerland & 201 & 889 \\
\hline UK & 394 & 1107 \\
\hline France & 360 & 740 \\
\hline Germany & 79 & 664 \\
\hline Italy & 463 & 954 \\
\hline Spain & 525 & 705 \\
\hline Netherlands & 281 & 495 \\
\hline
\end{tabular}

